\title{
Financing
}

agriculture and

rural areas in

sub-Saharan Africa

Progress, challenges and

the way forward

Richard L. Meyer

Working Paper

March 2015

\section{Food and agriculture}

Keywords:

Agricultural finance, rural finance,

sub-Saharan Africa, credit, savings 


\section{About the author}

Richard L. Meyer, Professor Emeritus, Ohio State University.

meyer.19@osu.edu

\section{Acknowledgements}

| acknowledge with great appreciation the support and many suggestions | received from Steve Wiggins in preparing this paper. Many professionals also graciously offered valuable suggestions. I cannot list them all but especially want to thank Dale Adams, Hugh Allen, Jamie Anderson, Gerhard Coetzee, Dean Karlan, David Kraybill, Geetha Nagarajan, Ajai Nair, Maria Pagura, Richard Roberts, Laura Viganò and Dora Waruiru. However, I alone am responsible for factual accuracy and for the views expressed.

\section{Produced by IIED’s Natural Resources Group}

The aim of the Natural Resources Group is to build partnerships, capacity and wise decision-making for fair and sustainable use of natural resources. Our priority in pursuing this purpose is on local control and management of natural resources and other ecosystems.

\section{Partner Organisations}

The Institute of Development Studies (IDS) is a leading global Institution for international development research, teaching and learning, and impact and communications, based at the University of Sussex. Its vision is a world in which poverty does not exist, social justice prevails and sustainable economic growth is focused on improving human wellbeing.

The Overseas Development Institute (ODI) is a leading independent think tank on international development and humanitarian issues. Its mission is to inspire and inform policy and practice which lead to the reduction of poverty, the alleviation of suffering and the achievement of sustainable livelihoods.

\section{Published by IIED, March 2015}

Richard L. Meyer. 2015. Financing Agriculture and Rural Areas in Sub-Saharan Africa: Progress, challenges and the way forward. IIED Working Paper. IIED, London.

http://pubs.iied.org/14652IIED

ISBN 978-1-78431-186-5

Printed on recycled paper with vegetable-based inks. 
In spite of investments and policy reforms, SubSaharan African countries lag in supplying financial services for agriculture and rural areas. New products, delivery channels, and partnerships, along with greater attention to savings, provide fresh optimism that this situation will be corrected. This paper examines several examples, with special attention to developments with savings groups and financial innovations with mobile phones and information and communication technologies (ICT). The telecom revolution and other innovations suggest that their use may leapfrog some difficult transportation and communication problems that drive up transaction costs and risks, and restrict financial inclusion for the poor.

\section{Contents}

1 Introduction

2 The slow process of developing African rural

financial markets

3 Developing rural financial services: the paradigm shifts from agricultural credit to financial inclusion 8

4 Major financial service providers

Banks

Microfinance - progress and limitations

Member-owned financial institutions

Savings groups (SGs) and VSLAs

Financial linkages and agents

Telecom revolution

Investment mechanisms: substitutes and

complements for agricultural and rural finance

6

18
45 Risk management and mitigation strategies in support of finance 22

Credit life and health insurance

Index crop and livestock insurance $\quad 22$

Partial credit guarantees 23

Warehouse receipts systems (WRS) 24

Credit scoring $\quad 25$

\begin{tabular}{ll}
6 Financial infrastructure & $\mathbf{2 6}$ \\
\hline Collateral registries for movable property & 26 \\
Credit bureaus & 26 \\
Term finance and land as collateral & 27 \\
7 The way forward & 28 \\
\hline & \\
References & 30 \\
\hline
\end{tabular}




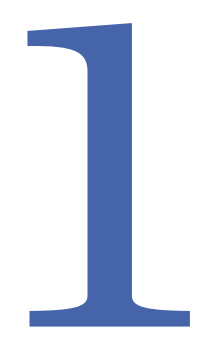

\section{Introduction}

The image of sub-Saharan Africa historically has largely been that of a poor region subject to frequent famines and conflicts, but is viewed today as a rapidly urbanising region with rising per capita incomes. It ranks second in population growth in the world and boasts 16 of the 29 economies projected to grow the fastest during 20122014. Rising world food prices have renewed interest in its potential to meet the world's demand for food and fibre. Structural reforms and improved governance have sparked foreign investments, and some countries are now able to borrow on favourable terms in world capital markets. The telecom sector has especially captured considerable attention as it has helped leapfrog some of the region's well-known transportation and communication constraints and spawned widespread innovation in finance.

Access to banking and financial services has improved but continues to be troublesome, especially for farmers, rural people, the poor and women. Most Africans have limited access to commercial banks. There is an average of just 6.8 commercial bank branches per 100,000 adults, and many countries have considerably fewer branches, including Malawi, Tanzania, Ethiopia, the Democratic Republic of Congo and Sierra Leone (Ardic et al., 2013). Microfinance institutions (MFIs) supply financial services to the poor, but do not yet reach most enterprises and poor households in semi-urban and rural areas where bank branches are sparse. Member-owned financial institutions are important in mobilising savings, but many are small, suffer governance problems, are slow to modernise and serve few rural households. As a result, financial services continue to be identified as major constraints for agriculture. Policies designed to ease constraints are widely viewed as ineffective or too slow, especially for smallholder farmers.

The purpose of this paper is to summarise innovations, along with their strengths and limitations, used to improve access to sustainable financial services for agriculture and rural areas in sub-Saharan Africa, with a special focus on smallholders. Section II reviews the impediments to the progress of developing rural financial markets, followed by a section outlining the evolution in paradigm shifts in analysing such markets. Section III summarises the role and constraints of the major categories of financial services providers beginning with the most formal institutions, banks, and ending with the least formal, savings and loan groups. The use of financial linkages and agents, the explosive growth of mobile phones for financial services and the emergence of investment mechanisms concludes the section. Section IV reviews strategies to reduce and manage risks including insurance, partial credit guarantees, warehouse receipts systems and, finally, the emergence of credit scoring to reduce the information costs of credit screening. Section V summarises the status of financial infrastructure investments made to benefit the entire financial system in collateral registries and credit bureaus. Section VI discusses the impediments for term finance and why the lack of land for collateral is one of the explanations. The final section outlines the way forward with an emphasis on savings groups and mobile finance. 
The paper is based on analysis of available literature and documents, supplemented by discussions with persons knowledgeable about specific subjects.

Caution is required in interpretation, as much of the information is about specific examples and case studies - so there are limits to generalisability for the entire region. Moreover, several studies use questionable methodology and the results may not be robust. The information also mostly reports positive results with fewer reports about failures. Few studies of innovations provide evidence about the distribution of benefits between suppliers and users of financial services.

Space and time do not permit consideration of the expanding information emerging with insights about client preferences and demands, the nature of rural client preferences and the development of clientcentred products and services. Generally, estimates of probable demand and usage of new products and services tend to be exaggerated. 


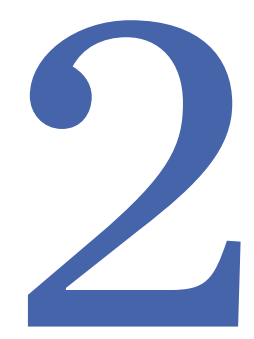

\section{The slow process of developing African rural financial markets}

Creating competitive financial markets with sustainable and efficient institutions to serve large numbers of savers and borrowers has been a slow process everywhere, but often slower in Africa. The reasons are many and resolving them is a long and expensive process. In an ideal credit market, loans are traded competitively and interest rates are determined by supply and demand. The best investments are financed because investors with the best projects are willing to pay the highest interest rates. In practice, however, credit markets diverge from the ideal (Besley, 1994). In credit and insurance markets, there is asymmetric information (access to different information) between buyers and sellers, so 'bad' products or services are more likely to be selected. This may lead to adverse selection. For example, a lender or insurance company may set one price for loans or insurance cover but there is risk of the loans or insurance being adversely selected by more risky or less profitable customers. Raising interest rates or insurance premiums may lead low-risk customers to drop out of the market, leaving only a pool of high-risk customers willing to pay the higher costs. Moral hazard may also occur because one party to the transaction - the borrower or purchaser of insurance - makes the decision about the amount of risk to take, while the other party - the lender or insurance company - bears the cost if things go badly. With imperfect information, lenders and insurance companies engage in costly actions to screen customers and to enforce contracts.

Lenders must evaluate the borrower's reliability, capacity to repay and intention to use borrowed funds wisely. The borrower may promise to work diligently to repay, but if default occurs, it is difficult for the lender to determine if it was due to bad luck, mismanagement or unwillingness to pay. Lenders try to overcome screening and contracting enforcement problems by requiring loan collateral or collateral substitutes, charging higher interest rates or lending only to borrowers with proven repayment records or with diversified and reliable cash flows. Or they may simply choose to deny loans, especially to poorer borrowers with few assets to offer as collateral.

Agriculture creates special challenges for financial institutions due to its spatial and risk characteristics (Binswanger and Rosenzweig, 1986). Land is immobile; production is dispersed; transport, communication and travel costs are high; and the seasonality of production creates big gaps between receipts and expenditures. 
Several kinds of risks and uncertainties exist: (1) yield risks due to weather, diseases and insects; (2) market price risks due to local and global weather and market variations; (3) timing uncertainties due to farm-specific weather variations; (4) uncertainties in the timing of repairs and reinvestments; and (5) illness, accidents and other lifecycle risks.

These characteristics create liquidity management problems for financial institutions because many borrowers borrow at the same time at planting and repay at the same time at harvest. Covariance of yields implies covariance of default risks, and lenders must carry cash reserves to meet depositor withdrawals at times when borrowers may be slow or unable to repay. High communication costs make it difficult to manage large banking networks needed to reduce covariate risks. In the absence of insurance, only small loans will be made without collateral. The most valuable collateral are assets that (1) are easiest to appropriate in the case of default, (2) do not easily lose their value and (3) have high use value to the borrowers so they will not want to part with them. Land tends to have the highest collateral value, but many African farmers do not have titles to the land they operate and often there is no active land market for lenders to liquidate land seized as collateral. Poor borrowers possess few high-quality assets to pledge as loan collateral so they are likely to be denied loans unless they can provide lenders with acceptable collateral substitutes.

The characteristics of agriculture also have important implications for insurance markets. Expected and actual yields differ enormously by field and farm, and average plot sizes are small, implying high costs for loss assessments. Insured farmers may be less careful in their animal and plant husbandry practices because some losses will be borne by insurance. Yield risk introduces covariance risk, and large insurance pay-outs require holding large financial reserves against losses. Typhoons, hurricanes, droughts and other catastrophic events are important weather risks, and the smaller the country, the more difficult it is to diversify risks across a large area. ${ }^{1}$

In the absence of formal financial and insurance markets, rural families have learned to rely on traditional strategies and informal credit, savings and insurance arrangements. These include maintaining a minimum of cash reserves, employing traditional production technologies, using conservative input levels and maintaining reciprocal social ties that provide aid in the event of emergencies. Many resist using formal financial institutions because of the high transaction costs of traveling to distant locations, lack of trust in their ability to access their savings or loans in emergencies and unattractive features such as the need to attend group meetings or accept the responsibility of group loans. In most countries, therefore, richer households and salaried workers access formal regulated financial institutions in urban areas, while mostly unregulated informal or self-regulated member-owned arrangements dominate rural areas. ${ }^{2}$

Financial sector development programs designed to reduce these problems have produced disappointingly limited results in Africa. Low levels of financial intermediation, relatively high interest rates, wide intermediation spreads and substantial bank profitability persist. The causes include currency and macroeconomic uncertainties, high government demand for loan funds, lack of competition, relatively small bank sizes and contractual problems including weak creditor rights, compromised courts, a deficient insolvency framework and a general disrespect for contracts (Honohan and Beck, 2007).

Faced with these problems, governments often create rules, regulations and interest rate and other subsidies to encourage lending to underserved borrowers, especially for agriculture, small and medium enterprises, and the poor. Relatively less attention is placed on offering safe and attractive places for the poor to save. Not surprisingly, quick-fix efforts to increase formal credit have produced patchy results because they do little to address underlying problems and challenges.

Success is more likely with investments in capacity building and long-term institutional development at multiple levels.

The recent emergence of new products, delivery channels and partnerships, along with greater attention to savings, however, provide fresh optimism that the traditional challenges will eventually be overcome. Examples are discussed in the following sections.

\footnotetext{
${ }^{1}$ It is difficult for most insurers and reinsurers to diversify their risks internationally.

${ }^{2}$ Recent careful analysis of poor households reveals many informal financial arrangements used by the poor to meet financial needs. See, for example, Collins et al. (2009). Earlier studies showed how informal finance is also used by non-poor households to complement formal finance. For example, see Adams and Fitchett (1992)
} 


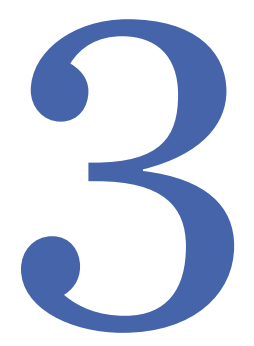

\section{Developing rural financial services: the} paradigm shifts from agricultural credit to financial inclusion

The approaches used to stimulate the development of financial services for rural areas have evolved over time, as the challenges are better understood. Beginning in the 1960s, subsidised agricultural credit programs were popularised as a way to correct the market failures thought to be the cause for the small amount of credit allocated to agriculture. These programs usually imposed interest rate ceilings that undermined the health of the financial institutions delivering credit. Eventually this rather naïve supply-leading approach was largely declared a failure so, by the 1980s, government failure replaced market failure as the fundamental problem. ${ }^{3}$

A new approach emerged known as the financial systems paradigm, which encompassed financial institutions, markets and instruments, the legal and regulatory environment, and financial norms and behaviour. The approach argued for relaxation of interest rate controls and developments at the micro, meso and macro levels. These views conveniently coincided with the emergence of microfinance that supplied small, usually non-collateralised, relatively high interest rate loans to the poor who lacked collateral required by banks.

Microfinance initially emphasised outreach to the poor, especially to women. Today, this is often referred to serving the bottom of the pyramid. By obtaining a MFI loan, it was expected that poor borrowers would take the first step up the financial ladder and eventually graduate to full-service formal financial institutions. Critics objected to the excessive focus on credit and, later, robust impact studies questioned how much credit alone could lift people out of poverty. ${ }^{4}$ Two additional views then took shape. First, MFIs began

${ }^{3}$ For the most cited critique of the agricultural credit approach, see Adams et al. (1984).

${ }^{4} \mathrm{~A}$ large number of microfinance impact studies have been done. Many have been criticised for using weak methodologies that produce biased results. Studies using a more rigorous random control trial methodology have produced mixed results regarding the claim that microfinance makes a major contribution to poverty reduction. The most recent example was reported by Banerjee et al. (2015). These results plus earlier studies of agricultural credit cast doubt on the impact of providing large amounts of credit unless other constraints are also reduced. However, a major limitation of rigorous random controls is that they usually focus on short-term results and so cannot capture the potential positive effects of long-term access to improved finance. 
experimenting with broadening their services to include savings, insurance, remittances and other financial services. Second, agricultural value-chain finance was proposed as a complementary strategy to the financial services approach. ${ }^{5}$ Value-chain studies have subsequently focused largely on how financial services could be increased for the small share of smallholders that participate in chains that are tightly structured. ${ }^{6}$ Most analyses, however, fail to estimate how much smallholders actually benefit compared to other agents in the chains. ${ }^{7}$ Moreover, the focus on a specific product or enterprise rather than the entire farm and non-farm activities that constitute a poor household's livelihoods misses the full range of financial services that may contribute to a household's welfare. ${ }^{8}$

The concept of financial inclusion emerged in the 2000 s as an even broader way to rationalise the need to develop financial services. It implies that everyone should have access to full suite of quality financial services, at affordable prices in a convenient manner with respect and dignity, delivered by competitive suppliers. Further, the services should match client needs, provide good value and avoid causing harm (CFI, no date). The objective of financial inclusion has become widely accepted as reflected in the Alliance for Financial Inclusion network (AFI, no date). Extreme views of the concept envision a cash-light or even a cash-free economy.
Achieving full inclusion is a distant objective for most developing nations, but has spawned an explosion of ideas and innovations to expand access to and use of financial services, many involving modern information and communication technologies (ICTs). Several will be identified in this paper along with the obstacles to make them a reality in rural areas and applicable for smallholders. A frequent shortcoming is the lack of evidence that improved access to a particular service, such as digital access to payments or remittances, will necessarily lead recipients to move up the financial ladder to more comprehensive formal financial services. ${ }^{9}$

${ }^{5}$ Agricultural value chain finance refers to the financial flows among actors within a value chain and flows to actors from outside the chains (Miller and Jones, 2010).

${ }^{6}$ An estimated 35 million of the world's 500 million smallholder farmers participate in tight value chains, meaning that they are generally less poor, operate at least two hectares of land and take a more business-like approach to farming than other smallholders. See Christen and Anderson (2013).

${ }^{7}$ One exception found a puzzling gap between positive impacts on enterprise income but lack of impacts on household income. This might be explained by methodological limitations in the analysis. See Dunn (2014)

${ }^{8}$ See a broader analytical framework presented in USAID (2011). A policy statement of how support for value chain finance differs is found at e-MFP (2011).

${ }^{9}$ For a proposed hierarchy of financial inclusion, see Jain et al. (2014). A digital pathway of financial inclusion is presented in Radcliffe and Voorhies (2012). These are useful conceptual frameworks but the actual hierarchy of financial services preferred by individual households or persons will obviously vary. 


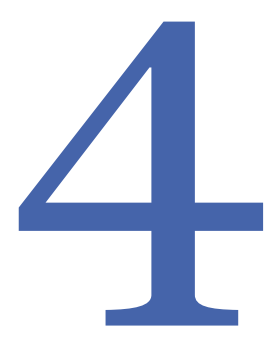

\section{Major financial service providers}

This section discusses the major categories of African financial service providers (FSPs), their role in supplying financial services and constraints faced in serving agriculture and lower-income rural and urban populations.

\section{Banks}

All African countries have regulated domestic and foreign-owned commercial banks that supply financial products and services to businesses and households. Many report an increased interest in agriculture Trade and Export Finance $(2014)^{10}$ but agricultural loans made by banks usually represent less than 5-10 per cent of their total portfolios (CABFIN 2014). They normally limit agricultural lending to large farmers, estates, plantations, agribusinesses, out-grower schemes and export crop value chains. Some lend to well-managed cooperatives, farmer associations, MFIs and rural businesses for onlending in cash or kind to producers. A few attempt to downscale and make microfinance loans. Some banks, such as Equity Bank in Kenya (Wright and Cracknell, 2007) and Société Générale de Banques au Sénégal (Riquet and Debuchy, 2015), are examples of dynamic commercial banks using innovations to reach nontraditional markets.

A common complaint is that the high cost structure of banks is a constraint for engaging in small transactions with individual clients, and most invest too little to learn how to serve agriculture. Still, banks represent the best potential to serve rural areas. They often expand branches to tap rural savings and have the greatest potential to diversify risks geographically. The back office operations established for serving urban areas can be modified to serve other market segments, and their use of automatic cash machines (ATMs) and other innovations can also be used to drive down rural costs. They usually have the most resources to invest in new staff and products to serve new market segments. Since they are regulated, they represent the lowest risk for rural savers.

Agricultural and development banks (state-owned and cooperative) were frequently created during the subsidised credit era. Most performed poorly and piled up mountains of unpaid loans that overwhelmed any good they achieved. Since it would be difficult to successfully reform them, a number were closed or privatised. However, advocates supporting reform began in the early 1980s to emphasise their potential if correctly revamped to serve the rural poor (Seibel, 2000). The successful reforms of the Unit Desa system of Bank Rakyat Indonesia, the Agricultural Bank of Mongolia and the National Bank of Commerce in Tanzania were offered as evidence.

Successful bank reform usually required two prerequisites. One, governments were fully committed to reform and to creating a firewall to protect the reformed bank against political interference. Two, reformed institutions needed to develop products and services for multiple categories of clients, such as microenterprises

${ }^{10}$ Through partnerships and minority investments, international banks are engaging with African banks and this may introduce more dynamism in their agricultural finance. 
and rural non-farm businesses, to reduce the risks of loan portfolio concentration and income covariance. Notwithstanding this largely negative history, there are still supporters for special agricultural banks. Tanzania recently announced the creation of a new agricultural bank and Uganda is currently debating a proposed specialised Land and Agricultural Bank.

A few countries created unit rural banks expecting that locally owned and operated FSPs would successfully serve heterogeneous local markets. The best-known African example is the rural and community banks (RCBs) in Ghana (Ajai and Fissha, 2012). They are fully owned by individual local community residents and currently number over a hundred with almost 600 outlets. They had a market share of 67 per cent of depositors and 48 per cent of borrowers in rural areas in 2008 and reportedly reduced rural credit constraints. It is unclear how many loans are made to agriculture because most are included in the reported 41 per cent market share of microcredit loans. An apex bank was created to aid with clearance functions. Historically, the network suffered from capacity constraints, unfavourable operating environments, excessive directed lending requirements that limited flexibility in managing risk and covariant risk in a major drought, leading to poor performance and closures. Several of these problems continue. Moreover, competitors are becoming more prevalent and are undermining the RCB advantage in serving local markets. ${ }^{11}$

Several measures have been tried to nudge banks to become more active in rural areas, such as setting minimum quotas for agricultural lending, requiring the opening of rural branches in exchange for licenses to open urban branches, and subsidy auctions for opening new branches. There is little conclusive evidence that regulations or incentives make a significant contribution unless the bank is committed to expand into rural areas. ${ }^{12}$ In Namibia, Bank Windhoek credits the grants of the Department for International Development (DFID) for sharing the costs of designing strategies, products and services needed for new community banks built in sparsely settled rural areas with poor infrastructure and where agriculture largely consists of livestock producers who have only a few seasonal sales and savings deposits (Napier, 2010).

\section{Microfinance - progress and limitations}

MFIs make small loans mostly to the unbanked poor, usually with few assets required as loan collateral by banks. Non-governmental organisations (NGOs) that offered microcredit were highly touted beginning in the late 1970s for their ability to reach the poor and lift them out of poverty with microcredit. Today, MFls serve many poor households in Africa with opportunities to save and to receive loans. As of August 2014, 262 MFls reported to the MIX Market with a total of 7.4 million borrowers and US $\$ 7.8$ billion in gross loan portfolio (MIX Market, no date). The region is unusual because more clients are served by savings-led MFls than by credit-only providers. The small average size of accounts suggests the majority of clients must be poor savers (MIX Market, 2013). Although many MFIs pursue objectives beyond savings and credit, this section focuses on their traditional financial services.

MFIs are heterogeneous, including banks that downscale to serve lower-income market segments, traditional savings-led member-owned institutions and NGOs, some of which aspire to achieve some type of regulated bank status. There are countries with a special MFI regulatory framework that determines if they can accept deposits and transact with only members or the general public. ${ }^{13}$

Group lending with peer screening of clients and peer pressure to assure repayment was the standard model until MFls began to experiment with individual loans. ${ }^{14}$ This technology performs best in densely populated urban and semi-urban areas where large pools of potential clients with multiple cash inflows can pay frequent instalments for small loans. Over-lending in urban markets and the search for sustainability by MFIs contributes to their search for new markets in semi-urban and rural areas. Successfully serving small farmers involves a total institutional commitment including modifying products, adopting individual lending, hiring specialised loan officers and modifications in management information systems to track individual loans with irregular payments. ${ }^{15}$

\footnotetext{
${ }^{11}$ The Philippines also created hundreds of unit rural banks in the subsidised credit era of the 1970s and experienced similar difficulties. Some survived and have become more viable by modernising and adopting microfinance methods and ICT applications.

12 There has been considerable analysis of India's aggressive policy of bank branching and credit controls beginning in the 1970 s. One study suggested that the availability of banks was a more important determinant of fertiliser demand and aggregate crop output than interest rates (Binswanger et al., 1993). A related study suggested that the impact on agricultural output of the requirement to expand branches and loans was modest at best but had a greater impact on the non-farm rural economy (Binswanger and Khandker, 1995). A third study concluded that the policy of branch expansion into rural unbanked locations significantly reduced rural poverty through increased deposit mobilisation and credit disbursement but the costs and benefits could not be estimated (Burgess and Pande, 2005).

${ }^{13}$ The multi-tiered example of regulations in the Cameroon is described by Fotabong (2012).

${ }^{14}$ The power and limitations of group lending was tested in Malawi (Simtowe et al., 2006).

${ }^{15} \mathrm{~A}$ study in Latin America identified how several of these factors contributed to MFI success in agricultural lending (IFC, 2014).
} 
Two MFI models of agricultural lending demonstrate different approaches. The German firm Internationale Projekt Consult (IPC) was a pioneer in adopting individual loans for farm lending using a credit-only approach. It successfully created a profitable product for an El Salvador NGO, and later transferred it to Centenary Bank in Uganda. Cash flow analysis is used to evaluate borrower repayment capacity. Small loans in Uganda started at roughly US $\$ 60$ for a term of three to six months and, after successful repayment, borrowers could graduate to larger loans. Various types of collateral and collateral substitutes are accepted (Meyer, 2014). Agricultural loans today are reported to be about 19 per cent of the total loan portfolio.

A group lending credit-plus approach that assists farmers with input acquisition and marketing is followed by the Opportunity International Bank of Malawi. It began as a savings-led commercial bank that targeted economically underserved people. Lending is done through groups of 10-30 persons, mostly women. It has tested several innovations to expand rural access including: (1) fixed outlets (mobile units, kiosks and satellite centres) and mobile vans; (2) ATMs; (3) Point of Sale devices through participating retail outlets, gas stations, agricultural supply shops and competitor banks; and (4) smart cards issued with biometric identification (Kalanda and Campbell, 2008). Analysis of mobile van use plus an advertising campaign showed that savings accounts and loans increased. Even though the van may reduce some costs, many households preferred using informal sources, including money lenders, landlords, Rotating Savings and Credit Associations (ROSCAs), friends, neighbours, relatives and local grocery stores because of lower transactions cost (Sharma and Nagarajan, 2011). GPS-supported systems were tested to verify plot sizes and aid in setting application rates for crop inputs and reporting yields. It is unclear if the high costs of these innovations are compensated through increased revenue or if they require subsidisation. Many of these innovations were also adopted by Opportunity Bank in Mozambique (AgriFin, no date).

MFIs are experimenting with mobile phones and other ICT applications to reduce costs and risks, but there is little information about their effectiveness. ${ }^{16}$ They face limitations in serving agriculture. To minimise risks, they must limit the size and length of loans and total portfolio exposure to agriculture. They generally cannot fund the larger and longer-term loans often required for successfully developing value chains. Their interest rate structure may be higher than some farmers and enterprises can pay, so rural non-farm firms with upstream and downstream linkages to farming may be better customers. Some MFls experience sufficient strength and become large enough to convert into microbanks, especially if there are special MFI regulations. Strong MFls attract external investors and grants, and loan from banks but many have not reached high levels of efficiency and self-sufficiency. Credit-plus MFIs seek grants and soft funding to fund non-credit services and some, such as the famous BRAC NGO in Bangladesh, reach huge scale with this approach.

MFls in sub-Saharan Africa have high operating expenses of 19 per cent compared to global levels of 14 per cent. The reasons are the high staff costs common in markets where skilled labour is scarce, high transaction costs of reaching rural areas and high costs of managing savings. The regulatory framework can be a constraint while supervision has often been weak. Seventeen of 48 sub-Saharan African countries had interest rate caps in 2010 and there are threats of ceilings being imposed in other countries (CGAP/ MIX, 2011). ${ }^{17}$ Caps often impose a large gap between the ceilings and the real FSP cost structures. This factor contributed to weak MFls being placed under government administration. ${ }^{18} \mathrm{~A}$ study of MFI rural finance operations mostly in West Africa reported that smaller loan sizes in rural compared to urban areas negatively affected their sustainability (De Bruyne, 2014).

A study of 30 greenfield (newly created) MFls started by holding companies in 2000-2012 demonstrates the challenge of creating sustainable FSPs in Africa (Earne et al., 2014). They are spread over 12 countries and are regulated, mostly deposit-taking institutions, focusing on micro and small businesses. By 2012, they together had more than 700,000 loan accounts, loans of US $\$ 527$ million and almost two million deposit accounts with a balance of US $\$ 445$ million in 700 branches employing more than 11,000 staff. Several were created by IPC which, after trying both bank downsizing and NGOfirst models, concluded that the fastest way to achieve profitability while serving lower-income clients was to start greenfield banks. ${ }^{19}$ AccessHoldings started six

\footnotetext{
${ }^{16}$ One robust effort to evaluate effectiveness is found in Cull et al. (2014).

${ }^{17}$ They were the eight countries of the West African Economic and Monetary Union (WAEMU) plus Ghana, Guinea, Eritrea, Mauritania, Namibia, Nigeria, Sudan, South Africa and Zimbabwe (CGAP/MIX, 2011).

${ }^{18}$ For example, as of June 2010, BCEAO, the regional central bank for West Africa, reported that 13 MFIs in the eight countries of WAEMU were under government administration. See ibid.

${ }^{19}$ Recently ProCredit sold its operations in Africa except in the Congo and system-wide eliminated all loans of less than US $\$ 5000$.
} 
greenfield MFI banks and all are expanding branches and expanding into agricultural lending.

The greenfield performance was compared with a peer group of MFls without strong network connections selected from the MIX database (MIX, no date). After operating for 60 months, the 30 greenfield MFls were considerably larger with greater outreach, higher loan quality, better profitability and were better capitalised and had more formal structures and deposit-taking infrastructure. Holding companies have the advantage of transferring knowledge and learning from one greenfield to another. No data were presented on loan sizes or types of clients so it is unclear if the greenfields serve the same market segment as the peer group. The greenfield portfolio yields of around 55 per cent imply they charge equally high interest rates.

On average, each greenfield bank starts operations with equity capital of approximately US\$4-5 million, and a budget for hiring start-up and technical assistance staff clustering around US\$4 million of which grants represent an average of US\$3 million. The cost of creating a greenfield deposit-taking branch in Eastern Europe was about US\$50,000 compared to US\$150,000-400,000 in Africa where operating costs are also higher. A simulation showed the expected internal rate of return at five years is approximately 1 per cent without grants, but approximately 14 per cent with the grants. Even a 14 per cent return is likely to be below what many development finance institutions (DFls) and social investors consider acceptable. Greenfield investments may be financially promising, but this is not likely to happen over a period of 5-8 years, which may be what investors would consider a reasonable time horizon.

Greenfield expansion has slowed in Africa and about 25 countries have none. This suggests that investors have concluded that they offer less favourable financial prospects, and points to the financial challenge that African FSPs face in supplying sustainable services. The challenge must be even greater in smaller markets with dispersed rural and farm populations and the agricultural environment is less favourable.

\section{Member-owned financial institutions}

Member-owned FSPs, sometimes called communitybased financial organisations, are a heterogeneous category that includes traditional indigenous ROSCAs and accumulating savings and credit associations $(\text { ASCAs })^{20}$, Financial Service Associations (FSAs) ${ }^{21}$ and more formal cooperatives and savings and credit cooperatives (SACCOs; commonly known elsewhere as credit unions), some of which are registered and (usually) lightly supervised. As noted in the next section, a new effort is being made in many countries to create small informal savings groups and village level savings and loans associations (VSLAs) that operate similarly to indigenous ASCAs.

Thousands of these FSPs with millions of members exist in Africa, and an estimated seven per cent of the African population belongs to cooperatives. For example, as of 31 December 2012, Kenya reported 215 deposit-taking SACCOS, of which 124 had been licensed. Total membership was about three million (SASRA, 2012). One of the largest has over 80,000 members. There are also about 136 rural-based FSAs with a total membership of about 780,000 . Memberowned FSPs should have an advantage in serving poor and distant populations because they use member volunteers rather than paid employees. However, most have a chequered history and generally have not been innovative leaders for either micro or agricultural finance. An International Labour Organization study concluded that the problems in many countries can be attributed to using cooperatives to serve state interests (Develtere et al., 2008). Especially in the Anglophone region, they have often been engulfed in state politics, so the solution is to disentangle from the state and to operate on business principles.

Some financial cooperatives are huge and successful, while others are small, suffer from poor governance and resist modernisation despite considerable foreign assistance. ${ }^{22}$ Member-owned organisations face a basic conflict because the members are simultaneously users and owners. ${ }^{23}$ They can be successful when conflicts

\footnotetext{
${ }^{20}$ ROSCAs typically are autonomously formed groups composed of several members that meet periodically to pool savings and distribute the 'pot' to one member. They continue meeting until every member has received the pot. ASCAs are similar except that savings can be accumulated and lent to members and non-members.

${ }^{21}$ The K_REP Development Agency of Kenya has developed several FSAs in Kenya and other African countries. FSAs are registered under the Companies Act as companies limited by shares. They are run explicitly as profit-making businesses. Dividends are generally higher than for cooperatives because of their business orientation. Unlike cooperatives that operate with one vote per member, the voting rights of FSAs depend on number of shares held up to a pre-set maximum (often 10 votes per person). This encourages more active governance/oversight from individuals with larger numbers of shares. They are principally investor-driven, reflected in high interest rates for borrowers, and zero interest rates for depositors. See Wright et al. (2000).

${ }^{22}$ See Meyer et al. (2004) for a discussion of the poor condition of many member-owned financial institutions in Uganda in 2004 and how government intervention complicated efforts to strengthen the sector. A USAID project to rehabilitate 14 SACCOs was terminated early in 2004 because they were slow to improve and reluctant to adopt modern techniques, design new products, adopt prudent policies, elect responsible board members and hire competent staff. A contributing problem was the overlapping responsibilities between the Registrar of Cooperatives, the Uganda Cooperative Alliance and the Uganda Cooperative Savings and Credit Union Ltd.

${ }^{23}$ The nature and types of these conflicts are discussed in detail by Cuevas and Fischer (2006).
} 
are managed and they are supported with a strong system of regulation and supervision.

The successful financial cooperatives usually meet two conditions. First, they have sustainable business models offering products and services at reasonable costs that members demand. They are cautious in growth, including rural outreach, and in expanding product range and client base. Second, they depend primarily on resources from members or cooperative networks rather than governments or donors. Often they are members of federations, associations or unions that provide technical backstopping and monitor performance and adherence to best cooperative practices World Bank (2007). ${ }^{24}$ Donors that are eager for fast results in strengthening cooperatives may be challenged by the need to follow a slower institution process of technical assistance and training. ${ }^{25} \mathrm{~A}$ World Bank project in Mexico is an example of using an institutional development approach to strengthen credit unions so they qualify for new regulatory requirements, and to assist them with ICT technologies used to incorporate rural members (WOCCU, no date).

\section{Savings groups (SGs) and VSLAs}

Several recent microfinance impact evaluations using randomised controlled trials found fairly modest positive impacts due to microloans and prompted more attention to finding sustainable ways to supply secure and valued saving services for the poor. ${ }^{26}$ International and domestic organisations now promote informal self-regulated SGs that operate similarly to ASCAs to help poor households manage their financial affairs as a complement to the many informal methods reported in the financial diaries. ${ }^{27}$ They are called Self-Help Groups in India, and are referred to as VSLAs in many African countries. At the end of 2014, an estimated 135,000 groups existed in 27 African countries with about three million members and average savings of US $\$ 30$ per member. ${ }^{28}$ Each consists of 15-30 members, usually women, who meet regularly to deposit savings in a fund for loans made to group members. At the end of a fixed cycle (usually 9-12 months), all savings with accumulated interest and fees are distributed among group members and a new cycle begins. Savings are held in a simple strong box, often with three locks with three members each entrusted with a key. In situations where members have few numeracy skills, no written accounts are used. ${ }^{29}$

Several advantages of SGs have been identified (Karlan, 2014). Member trust and governance skills are built through frequent liquidation and distribution of savings, and by conducting all transactions in the presence of all group members. No outside capital is required, the interest paid remains in the community, the project costs of organising groups is modest and the commitment to save regularly may stimulate savings and reduce non-essential spending. Transitioning to larger and longer-term ASCAs generally requires adopting paper-based accounting, so training costs rise although much of the training is done by volunteers recruited in training-the-trainer programs. With or without further assistance, some groups build linkages with formal FSPs. For example, SGs in Nairobi slums grafted onto M-PESA telecommunications and banking for depositing their savings balances, and even facilitated group investments in the Kenyan stock market (Wilson, 2010). A limitation, especially for those with poor members, is their limited savings capacity and, therefore, the limited ability to intermediate large amounts of savings or offer larger and longer-term loans to their members.

A summary of randomised controlled trials conducted of SGs in seven African countries produced evidence of mixed impacts measured at the community level (not at the individual member level) (Gash and Odell, 2013). ${ }^{30}$ They successfully reached the poor but members tended to be wealthier and more financially active than non-members. The groups increased savings and credit use in treatment areas, but the findings about asset ownership, increased business-related spending, profits and the likelihood of a woman owning a business were mixed. There were also mixed and limited impacts on health and education spending and school enrolment.

\footnotetext{
${ }^{24}$ The worldwide credit union experience also stresses the importance of savings mobilisation for good governance. See Branch and Klaehn (2002).

${ }^{25}$ Guidelines have been identified for donor support for member-owned financial institutions in rural Africa but they are quite general and based on relatively few case studies. See Athmer and Bosch (2013).

${ }^{26}$ Six of these evaluations were recently published along with a summary article (Banerjee et al., 2015).

${ }^{27}$ A new book outlines the evolution of several international organisations that support the creation of savings groups (Ashe and Jagger Neilan, 2014).

${ }^{28}$ As reported in SAVIX (no date), a database for savings groups created from data supplied by several international NGOs that promote them. It does not include groups formed by domestic NGOs.

${ }^{29}$ The fact that groups are usually composed mostly of women helps reduce the gender gap in the use of both formal and informal finance. See Johnson and Nino-Zarazua (2011)

${ }^{30}$ The details about the Mali program, the study methodology and the detailed results are found in Beaman et al. (2014).
} 
A lively debate exists about whether or not linkages should be encouraged between SGs and formal FSPs. Advantages for both the SG members and FSPs have been identified (Bankable Frontier Associates, 2014a, 2014b). However, others have advocated caution saying that such linkages may undermine their strong savings orientation and reduce the attractive interest earnings of members who are net savers (for example see Allen, 2010). Moreover, most members are believed to seek ways to smooth consumption and meet relatively small expenditures such as paying school fees rather than save for larger business investments. Relationships among group members may be damaged if FSPs require that group savings be used as collateral for individual loans.

Through the Banking on Change partnership, Barclays Bank, CARE International UK and Plan UK are working to link SGs to formal banking services in Africa (Egypt, Ghana, Kenya, Mozambique, Tanzania, Uganda and Zambia), Asia (India, Indonesia and Vietnam) and South America (Peru). The specific approach is adapted to the conditions found in each country. The partnership reached over 500,000 persons in its first three years (Allan et al., 2013).

One of the most advanced linkages was developed in the pilot project of the CARE International Kenya partnership with Equity Bank and Orange Kenya (a mobile network operator) designed to link 200 mature SGs with Equity Bank. A mobile money application through mobile phones was created to facilitate access and reduce member transaction costs (Care International in Kenya, 2013). CARE identified the potential demand because groups reported problems such as insufficient savings to meet loan requests, security issues towards the end of a saving cycle when cash boxes have large amounts of cash, loan terms (1-3 months) too short for seasonal or agricultural businesses and loans for larger investments (more than US\$50) were not available and generally impossible to repay within the short term. Mature SGs could opt for participating in a linkage if there was a clear group consensus to do so. Considerable training was provided for all participants. The partnership created a special Equity savings account (Pamoja) linked with a new mobile phone application (Orange Money and Eazzy 24/7) that allows rural groups to manage their money through their mobile phones and Equity's extensive agent banking network. Both the groups and individuals open accounts making mobile cash transfers possible. Group officials can transact in Equity branches, via mobile phones during group meetings and through
Orange Money agents or ATM machines. Through an arrangement among Mobile Network Operators (MNOs), the users of any mobile phone in the country can access the application.

Providing opportunities for linkages needs to be carefully considered. Projects that provide strong incentives for linkages and for FSPs to lend to SGs will likely undermine them. However, most SG members in rural areas will not likely move up the financial ladder if they are left to autonomously link with FSPs. The process will be especially difficult in remote areas far from FSPs unless new technologies are used to reduce transaction costs. The expansion of mobile phones and agent banking may encourage FSPs and telecoms to actively seek SG savings as a way to protect against theft of the strongboxes, and this may lead to individual savings accounts and eventually to loans. ${ }^{31}$

An alternative path would be for some SGs to attempt to build on the trust and governance skills that members develop to evolve into informal SACCOs and later even into formal regulated status, but this would be a large and long-term undertaking. There is little evidence that they are moving in that direction, so linkages offer a more feasible path. Third-party facilitators, such as NGOs, may be critical to success but only if they have the resources and vision to train SG members properly and promote transparency and consumer protection policies.

\section{Financial linkages and agents}

Many types of linkages and agent relationships are used in finance to overcome barriers, expand market access and control costs. FSPs and telecoms are among the biggest creators and users of partnerships, alliances and agents (Gallardo et al., 2006). These relationships permit FSPs to access resources, reduce transaction costs, acquire technical and management skills, link up to banking technology and infrastructure, and expand access to financial services. To a greater or lesser extent, all such arrangements involve the principal-agent problem or agency dilemma that occurs when one person or entity (the agent) makes decisions that impact, or on behalf of, another person or entity (the principal). The dilemma exists because an agent is sometimes motivated to act in his/her own best interests rather than those of the principal. A variety of contractual and other methods must be used

${ }^{31}$ In August 2014, Airtel Uganda, Grameen Foundation and Plan Uganda launched a new group savings option to store their group's cash as mobile money (Grameen Foundation, no date). 
to minimise these problems. Agent relationships can take many forms. Sometimes they are exclusive and are similar to employees, such as the operator of a kiosk that sells airtime for one telecom. In other cases, a retail shop operator may have a business where one of many activities is to process operations for one or more banks or telecoms or even governmental agencies.

A FAO study analysed financial linkages between formal and less formal FSPs that expanded access to more and higher quality products and services (Pagura and Kirsten, 2006), with the focus on linkages serving the rural poor. For example, the Mali Banque Nationale de Développement Agricole supplies bulk loans, credit lines and savings accounts to Kafo Jiginew, the largest network of SACCOs, and CVECA-ON, a large village bank network, to manage cash flow variability and/or portfolio expansion. In Rwanda, the apex, Union des Banques Populaires de Rwanda, is able to penetrate into rural markets through its network with Peoples Banks (banques populaires - essentially credit unions). Privatised microfinance banks and financial NGOs use linkages to expand scale in competitive markets. Unexpected negative consequences can occur, however, when subsidised linkages stimulate FSPs to 'cream-off' existing MFI clients, crowd out potential entrants in the market and/or discourage the savings culture.

Successful linkages must resolve issues of contract design, risk and profit sharing and conflict resolution. Capacity building is needed at two levels. First, informal partners need strengthening to effectively manage savings and credit if they link with commercial banks, apexes, insurers and so on. Second, MFls need strengthening to build and maintain linkages, to design partnership contracts, to update management information systems (MIS) to track revenues and costs, and to evaluate the costs and benefits of partnerships. ${ }^{32}$

Many FSPs are entering into agent banking. An agent can be any retail entity, including post offices, lottery outlets, supermarkets and other small retail agents. They are not licensed to handle deposit or withdrawal functions on their own, but can do so on behalf of a FSP. Agents are also used by telecoms to sell air time and take on broader functions. As a form of branchless banking, FSPs use agents to avoid the expense of brick and mortar branches and to reduce the cost of conducting many small cash transactions for poor people (Dermish, 2011). Agents use ICT innovations such as mobile phones, debit and prepaid cards, tablets and card readers to conduct transactions with their partners. Some are also cash-in, cash-out (CICO) agents that convert electronic money into cash. Over the counter (OVC) agents perform payment transactions on behalf of customers who do not have a mobile money account with a mobile phone company. Some agents are authorised to open money market and bank accounts, but many are restricted to processing transactions. Creating, managing and supervising agents, providing them with an attractive business proposition, and creating a supportive regulatory framework with adequate consumer protections is a complicated task (for a Kenyan example, see McCaffrey et al. (2014). The widespread use of OVC agents for money transfers in some countries may be highly useful for people but not necessarily a good indicator of eagerness to use mobile money or for a cashless economy (see Arabehety, 2013).

The experience of Brazil demonstrates that agent banking alone does not necessarily lead to an expansion of the formal financial frontier in areas with few FSP branches. By 2013, Brazil had expanded into the world's largest network with close to 400,000 banking agents (called correspondents) while the number of bank branches remained relatively constant. The network is used for the county's huge conditional cash transfer system for the poor that is estimated to reach about 14 million households. An evaluation showed that agents generally did not make the hoped for contribution to financial inclusion (Sanford, 2013). Two-thirds of the population pays at least one bill with an agent, but only a minority uses them for other financial services. Only 12 per cent with bank accounts usually withdraw through an agent, 9 per cent deposit through an agent, only 6 per cent have accessed a loan and only 4 per cent have opened a bank account through an agent even though many agents are authorised to provide these services. However, because there is a tendency for those that use correspondents to be poorer, live in remote areas and are more likely to be women, agent banking makes a positive impact on financial inclusion for them. Improvements in service quality are required for correspondents to become wider conduits for financial access in Brazil and elsewhere.

\section{Telecom revolution}

The large number of Africans with access to mobile phones but not to formal financial services offers the potential for the most transformative innovation in financial services since the emergence of microfinance. The hotbed of this innovation is East Africa where mobile phone penetration is the greatest. FSPs are finding ways to use the technology to lower the transaction costs of expanding rural outreach, but telecoms are also directly competing with FSPs to provide financial services. Person-to-person (P2P)

${ }^{32}$ The conditions for successful linkages between formal and informal intermediaries were sketched out for Ghana (Jones et al., 2000). 
mobile payments are increasing and several countries have an objective of becoming cashless or cash-light societies. Mobile phones are also transforming the ways farmers and rural people access information, products and services that can indirectly support finance. For example, rural producers can more easily access market information leading to better price and market opportunities (Aker, 2010; Muto and Yamano, 2009) and the rural population can receive governmental support services and payments (Aker et al., 2012). This section highlights some key innovations and constraints.

Different business models exist for using mobile phones in finance: (1) direct banking channels, (2) MNOs that provide wireless communications services as technology and channel partners, (3) MNOs as bank agents, (4) institutions and retailers as bank partners, (5) direct customer channels with institutions as agents and (6) MNOs as direct FSPs (Chopra and Wright, 2011). Competition among these channels and the rules of the game set by regulators determine how the mix of channels evolves over time in each country.

A recent report from the leading information source provides a comprehensive view of mobile money developments (Pénicaud and Katakam, 2013). It is based on self-reporting by 98 service providers submitting information on mobile money, 21 on mobile insurance and 16 on mobile credit and savings. Mobile money is a service that allows financial transactions to be conducted over a mobile phone. It includes transfers and payments such as P2P and government-to-persons (G2P) transfers, bill payments, bulk payments, merchant payments and international remittances. Providers that offer mobile phones as just another channel to access traditional banking products are not included.

Mobile money was available in 36 of 47 African countries by 2013. Many have two or more mobile money services, implying a need for interoperability since most are closed loop systems requiring electronic money be converted to cash to send to someone using a competing service. There were 98 million registered mobile money accounts in sub-Saharan Africa with 34 per cent concentrated in East Africa. ${ }^{33}$ In seven markets, MNOs are permitted to provide mobile money services so they contribute directly to financial inclusion but most mobile accounts are inactive, suggesting cash transactions still dominate. Mobile money is offered through mobile wallets, but the most popular method is use of OVC agents performing transactions for unregistered customers. Almost 40 per cent of the agents reportedly were 'rural' but there is no standard definition of rural. ${ }^{34}$ Most agents were inactive and performed less than one transaction during June 2013. Even the active agents performed so few transactions that many may need to be eliminated, which may reduce rural access.

Almost three-quarters of total transactions are $\mathrm{P} 2 \mathrm{P}$ transfers and airtime top-ups with bill paying second in importance. Bulk payments including both salary payments and G2P payments is third, and less useful unless providers have a large distribution network capable of managing large amounts of liquidity. Companies and merchants have started to use mobile money to accept and make large-scale payments. ${ }^{35}$

Rural residents could benefit when mobile money becomes more widespread. For example, many already receive transfers from family members who migrated to cities and desire to send money home, and purchasers of farm products are beginning to make mobile payments to producers in value chains. Mobile insurance, credit and savings services are also potentially important, but the business case is challenging because providers must use sales forces to acquire customers rather than rely on mobile money agents. The most successful applications to date are in Kenya and Tanzania where mobile money has reached scale. ${ }^{36}$

Several mobile money providers offer mobile insurance, mostly life cover, with the balance offering health, accident or agricultural insurance. For example, the mobile provider Tigo in Senegal offers a 'freemium' product; customers are given a minimum of free insurance and can buy additional paid coverage. Within a year and a half, 180,000 subscribers qualified, with a majority opting for the paid version, suggesting a demand for life insurance. MicroEnsure offers a variation of this model in Ghana and Tanzania.

\footnotetext{
${ }^{33}$ In contrast to East Africa, a collaboration between UNCDF and the MasterCard Foundation expects that only by 2020 will $10-12$ per cent of the adult population in Benin, Senegal and Zambia be able to conduct financial services via mobile channels on a regular basis (UNCDF, no date).

${ }^{34}$ Additional analysis (ibid, page 25) was conducted of the geographic locations of financial access points, including commercial bank branches, ATMs, MFls mobile money agents, savings and credit cooperatives, and MFI deposit taking institutions in Nigeria, Tanzania and Uganda. It revealed that fewer poorer and rural people lived within five kilometres of a service point compared to richer and more urban populations.

${ }^{35} \mathrm{~A}$ new application is the use of mobile money by persons and businesses to pay tax obligations in Tanzania, Kenya and Mauritius (GSMA, no date).

${ }^{36}$ Kenya has the most registered mobile money accounts - more than the number of adults - while Tanzania has the largest ratio of mobile transactions to GDP (CGAP, 2014).
} 
M-Shwari, a credit and savings product offered by Safaricom ${ }^{37}$ to its M-PESA mobile phone customers in Kenya through a partnership with the Commercial Bank of Africa (CBA), is the best-known African example of savings and loans through phones. Safaricom has to manage a vast network of $\mathrm{CICO}$ agents to accept and pay out cash. Customers can apply for loans, open bank accounts and move funds from their mobile wallet to an interest-bearing bank account once they have been subscribers for at least six months. Past usage of Safaricom services determines initial loan limits, while subsequent loans are based on savings with M-Shwari and the repayment history of M-Shwari loans. Loan sizes are only up to US $\$ 235$, have a 30 -day term and require a facility fee of 7.5 per cent. Disbursements and repayments are made through M-PESA. Late payments trigger automatic roll-overs and a much higher interest rate. Deposit accounts at CBA have risen from 35,000 to over five million in less than a year to become the second largest Kenyan bank in number of accounts. ${ }^{38}$ In Tanzania, Vodacom has joined forces with the CBA to offer M-Pawa, which is similar to M-PESA.

Musoni, a Kenyan start-up MFI, uses local offices to acquire customers rather than rely on agents. Borrowers must have mobile money accounts for use in loan disbursements and repayments. It is partnering with First Access to experiment with credit scoring algorithms using airtime purchases and call history data (First Access, no date).

Celpay, a third-party payment company headquartered in the Netherlands, operates a mobile banking platform in the Democratic Republic of the Congo and Zambia. It offers deposit taking and a range of payment services in which customers can deposit and withdraw at participating registered banks and Celpay outlets. The target market is mobile payments through wallets between suppliers and distributional networks, breweries and MNOs. Business-to-business payments (B2B) for small businesses have been credited with bringing some of the unbanked into banks (Napier, 2010).

East Africa is clearly the leading region in these innovations, but actual usage is still in its early stages. The experience of mobile money, credit and savings to date suggests that much needs to be learned about customer acceptance, but they have the potential to meaningfully increase financial inclusion and reduce transaction costs for both suppliers and users. The ease of usage, structure of fees, nature of consumer protection and interoperability among providers will affect consumer acceptance.
Analysis suggests that future access and usage of mobile banking applications will depend on three sets of factors. First, there are issues of access to phones and charging facilities, and the possibilities that will arise with future technological developments with phones and $\mathrm{Wi}-\mathrm{Fi}$. Second is a need to develop trust among users who are not accustomed to dealing with banking, much less mobile banking, and to create products and services they really value. Third, the future structure and impact of the industry will depend on the competition and cooperation that develops between FSPs, banks and telecoms, and the nature of the regulatory regimes evolving in each country - for example, see Hammond (2010) and Porteous (2014).

Rural areas pose special challenges (Frydrych and Aschim, 2014). First, lack of infrastructure creates logistical challenges for agent and cash management. Second, rural customers have specific financial needs, so an effective value proposition for innovations must be tailored for them. Third, rural customers generally have lower literacy levels so a suitably user-friendly interface with the technology is required. Fourth, lack of formal identification documents requires regulatory solutions that facilitate customer adoption. To date, most providers have relied on a natural progression of expansion from urban to rural areas without thinking critically about ways to meet these challenges.

\section{Investment mechanisms: substitutes and complements for agricultural and rural finance}

Private and social investment is increasing in subSaharan Africa, and considerable attention is given to its role in expanding and modernising the region's agriculture. Several investment strategies are summarised in this section to demonstrate the potential for substituting for and/or partnering with FSPs. Some invest in start-up agribusinesses with the potential to grow and eventually obtain funding from FSPs. FSPs can also directly partner with government and development agencies, NGOs and private investors that increase borrower creditworthiness by reducing barriers in supplying inputs and technical services and improving market access. Many of these activities indirectly support finance through improved livelihoods

\footnotetext{
${ }^{37}$ Initial funding for the Vodafone/Safaricom pilot for mobile P2P funds transfer came from the DFID Financial Sector Deepening Challenge Fund. See Napier (2010).

${ }^{38}$ Field work has been completed for research being conducted on the impact of M-Shwari (IMTFI, no date).
} 
for farm and non-farm households so that they become better financial customers. Although many development projects do not involve explicit partnerships, donors have long advocated greater coordination. For example, USAID has introduced the concept of co-locate, coordinate and communicate for its projects and this will encourage more partnerships (for example see USAID/ Malawi, 2013).

Most private investment is believed to be channelled into larger scale projects, while some investment vehicles and development projects focus on value chains involving smallholders and smaller agribusinesses. The Dalberg Group argued for massive investments to support smallholders (Dalberg Group, 2012). It argued that the world's 450 million smallholder farmers (about 50 million in Africa) have a largely unmet global demand for finance as large as US $\$ 450$ billion. Social lenders and local state sources are estimated to satisfy less than two per cent of the demand. Social lenders largely work through cooperatives or producer organisations, and only about 10 per cent of the world's smallholders participate in such organisations. To meet the need, Dalberg proposed a strategy focusing on value chains with donors and impact investors providing foundational capital, multinational buyers working with lenders to facilitate financing with purchase contracts as collateral and commercial and social lenders matching their capabilities with relevant needs and opportunities.

Two initiatives grew out of the Dalberg report. The first, the Initiative on Smallholder Finance, will demonstrate how specific models and products can expand bank financing for smallholders (Global Development Incubator, no date). The second, the Council on Smallholder Agricultural Finance (CSAF), is an alliance of social lending institutions that target agricultural businesses in the 'missing middle' in low- and middleincome countries (CSAF, no date). The members will convene on a pre-competitive basis to exchange learning, identify best practices and develop industry standards covering market growth, responsible lending principles and social and environmental impact.

Although most MFls only supply microloans, many operate credit-plus programs and cover the cost of financial services with financial income, and use grants and soft funding to cover the 'plus' components. The target group generally is not the very poor, but one new approach has that objective. The CGAP/Ford Foundation graduation project developed guidelines for organisations that follow a five-step program in which grants and training are initially used to build household livelihoods for the very poor so that they develop the productive capacity to graduate eventually into standard microfinance programs. ${ }^{39}$ Ethiopia and Ghana were among the ten countries included in pilot programs (de Montesquiou et al., 2014).

Many private investors and development agencies target value chains rather than improving financial services for a wider range of customers. The role of development agencies is usually limited to facilitating rather than making direct investments. An example is TechnoServe's support of chains in Malawi and Tanzania. It recommends that facilitators assist chains to obtain financing rather than provide it directly or subsidise the costs of the business. The fact that a chain provides an assured supply of production inputs and a market for smallholders is often sufficient to reduce lending risks so that FSPs will provide financing (Miller and Jones, 2010).

A relatively new promising development is the creation of special private and social investment funds for investing in African agriculture. A forthcoming FAO report identified 63 agricultural investment funds, almost all funded by development-oriented investors including DFls and private foundations, that emphasise development impact (Miller et al., in press). The total capital base amounted to approximately US $\$ 5$ billion with recently established funds mostly smaller than the average size of US $\$ 80$ million. Over 60 per cent focus exclusively on agriculture and 25 per cent focus on Africa. Several have grant-funded technical assistance components. Although the profit objectives of these funds may naturally lead them to invest in larger firms, some benefits may trickle down to smallholders, especially those that support domestic small and medium enterprises (SMEs) gearing up to supply emerging African supermarkets. These investments may also encourage FSPs to supply working capital to the producers and non-farm firms in which the funds invest.

An Oxfam report, however, is cautious about the potential impact of socially responsible investment funds (Doran et al., 2009). High transaction costs and fund economics imply they will exclude small investments. With highly paid management teams, it is infeasible for them to make investments of substantially less than US\$1 million. Most funds are based in Europe or the US, so transaction costs are high unless they link with local agents or companies to facilitate deal-sourcing. Moreover, many countries will not attract investments because legal protections for investors are weak and exit options limited.

\footnotetext{
${ }^{39}$ The inspiration for this concept came from BRAC, the huge NGO in Bangladesh that designed an approach to serve the very poor who are unable to manage a standard microfinance loan. BRAC supports a variety of financial and non-financial products for millions in the country, and is one of the largest NGOs in the world (BRAC, no date)
} 
A rather unique investment approach is followed by AgDevCo, a non-profit social impact investor and agribusiness project developer involved in producing and processing food crops for national and regional markets. It promotes 'patient capital' through investments in early stage agribusinesses. It is a promoter or co-promoter of greenfield agricultural opportunities to support emergent commercial and small-scale farmers too large for microfinance but too small for private equity. ${ }^{40}$ The support continues until the businesses can attract private investors. Its investments range from US $\$ 250,000$ to around US\$4 million, and it seeks a return of around ten per cent per annum on debt. Some concessional finance may be used for projects with direct benefits for smallholder farmers. Total funding of more than US $\$ 100$ million has been supplied by several sources including private sources, and DFID, USAID, the Rockefeller Foundation, Alliance for a Green Revolution in Africa and the Africa Enterprise Challenge Fund. As of July 2014, it had invested US $\$ 43$ million in over 40 agribusinesses (AgDevCo, no date).

Root Capital, a member of the CSAF, is an example of a non-profit social investment fund that lends and also provides financial advisory services to African businesses too big for microfinance, but generally unable to secure credit from commercial banks. The loans range from US $\$ 50,000$ to US $\$ 2$ million to rural small and growing businesses. It lends short-term trade credit and pre-harvest loans with terms up to 18 months for purchasing products from farmer suppliers, and long-term fixed-asset loans with terms up to five years for investment in equipment and infrastructure. Since 1999, it reportedly lent over US\$500 million dollars to more than 400 businesses, which reportedly improved livelihoods for more than 500,000 rural households in Africa and Latin America (Root Capital, no date).

Another social enterprise, the One Acre Fund, uses a value-chain livelihoods approach in Kenya, Rwanda, Burundi and Tanzania to improve farm income (One Acre Fund, no date). It provides a 'service bundle' that includes education, finance, seed, fertiliser and market facilitation. Inputs are delivered to the farmer along with instructions on how to use them. It currently reaches over 200,000 farmers who mainly produce maize for home consumption, and plans to launch one new country per year. Field expenses include farm inputs and logistics, local staff, in-country headquarters and a 'HQ charge' paid to the international headquarters. The earnings cover about 80 per cent of the costs. Donor grants cover the operating shortfall along with significant R\&D expenses, including new country scouting, product innovation and service innovation.
Unlike many NGOs, it does not aim to work itself out of a job by developing local suppliers and markets, but plans to continue to serve farmers with other livelihood strategies. At the speed it is expanding, it may become the BRAC of Africa. ${ }^{41}$

Applications of crowdfunding are emerging as another potential funding source in developing countries to leapfrog traditional financial markets. They are channels for promising projects to raise funds over the internet from multiple individuals - see Raymond (2014) and infoDev/The World Bank (2013). They take many forms but are essentially a modern and extended version of the traditional way family and friends supply funds for new ventures. Their success depends on favourable regulations, modern ICT, cultural acceptance and the creation of trust between financial contributors and recipients. The funding can be provided as a donation or in exchange for a reward or prize at a later date, or as debt, or equity in the form of a percentage ownership in the venture.

Examples include Kiva.org through which over a million lenders have lent about US\$660 million in zero interest loans to almost $300 \mathrm{MFls}$ (field agents) for interest-bearing loans to selected clients. Kiva Zip uses social networking in a new pilot in Kenya in which the lenders make zero interest loans directly to entrepreneurs who must first obtain funding from 15 persons in their networks. Village Capital also employs a version of peer support when it selects entrepreneurs with projects to participate in a training program at the end of which they together decide which projects to recommend for funding, mostly through partner organisations. One training program was conducted in Kenya in 2014 and another is scheduled for East Africa in 2015 (VillageCapital, no date). In yet another example, since 2006 over 30,000 borrowers, close to 95 per cent women, borrowed low interest loans from social investors for microenterprises in India (Linkedln Pulse, 2014).

Several crowdfunding platforms have emerged for sub-Saharan Africa due to the increase in the middle class, rapid adoption of mobile technology and market need. One that conducts infrastructure projectbased crowdfunding is Homestrings (no date). It has demonstrated the power of tapping diaspora (nationals living abroad) investment interests. Between its launch in 2011 and February 2013, it reportedly mobilised about US\$25 million in funds with a range of products, projects, funds, bonds and public-private partnership opportunities. It covered 13 African countries with Kenya, Ghana and Nigeria the primary focus.

\footnotetext{
${ }^{40}$ The addition of patient capital may be necessary in order for private equity funds to reach smaller and riskier enterprises. See Silici and Locke (2013).

${ }^{41}$ See footnote 40 .
} 
The factors expected to be favourable to support crowdfunding were found to be a strong social media usage, high degree of early stage entrepreneurial activity, strong friends and family funding networks and access to education. Kenya was found to have improved in several categories, so it is not surprising it has been the focus of many initiatives. As important as crowdfunding may become, it is unlikely to make a significant impact on Africa's agriculture in the near future. First, many countries do not have the conditions conducive to its emergence. Second, conditions are not likely to improve enough in the near future so that investors will develop trust that their funds will be used as proposed. Third, the successful entrepreneurs will be those most capable of communicating compelling stories about their business prospects and will be backed up by credible peers or the 'crowd'. These entrepreneurs will demonstrate they have the knowhow to access export markets or serve high-end local markets, such as the small Kenyan business Ojay Greene (www.ojaygreene.com), which has been a Kiva borrower and was selected by peers for funding during the Kenyan Village Capital training program (see YouTube, no date).
There has been little analysis on the impact of the investment vehicles described above. Evaluations are needed to determine if foreign investment crowds in or crowds out domestic investment ${ }^{42}$ and if it induces FSPs to become more active in rural areas and in agriculture. Although individual enterprises may benefit from improved access to investment capital, the macro impact may be limited. If investors cherry-pick the most promising and less risky projects, there will be fewer spill-over effects compared to a venture capital strategy of selecting challenging but promising projects, and using subsidies for technical assistance and local training and management. Important learning about the potential returns and risks of investing in agriculture can only occur if investors share experiences, both good and bad. Preparing smallholders for private sector investment is as important as preparing investors to invest in smallholder production (USAID, 2014). Moreover, investors may have already exhausted the best opportunities for high return, low-risk export crops leaving the harder task of nurturing SMEs that target local markets and the smallholders that sell to them.

${ }^{42}$ A Ghana study concluded that for the period 1976-2007, foreign investment tended to crowd in domestic investment in agriculture (Gameli Djokoto et al., 2014). 


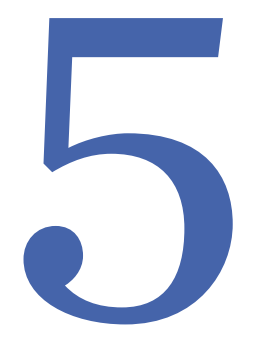

\section{Risk management and mitigation strategies in support of finance}

Several strategies are being employed in Africa to reduce and manage risk for FSPs and households. For example, credit guarantees and warehouse receipts schemes are being implemented with the hope that they will induce more lending by FSPs. Insurance is also offered to households to help them manage risks with spill-over benefits also expected for FSPs. This section reviews these strategies.

\section{Credit life and health}

\section{insurance}

Microinsurance is one of the most rapidly expanding microfinance products intended to help the poor respond to emergencies. The objectives are as varied as improving access to health care, increasing food security and coping with climate change. Insurance is marketed directly by insurance companies or in partnership with MFIs and other organisations that work with the poor. Occasionally MFIs design their own microinsurance programs.

A significant proportion of Africans with life insurance have credit life that covers the outstanding loan principal and interest upon the death of the borrower (Vargas Hill et al., 2014). It is often automatically bundled with loans. When borrowers learn the benefits, it is hoped they will become receptive to other insurance products but they may also respond negatively if they perceive little value. For example, dropouts rose when an Indian MFI bundled health insurance with loans because borrowers did not want to pay higher interest rates. This led to a fall in business profits (Banerjee et al., 2014).

The lack of understanding about health insurance, high costs due to limited scale and the resulting low uptake constrain its development. A study of microinsurance schemes identified factors associated with successful scale (Thom et al., 2014). The majority of market-based schemes that reach scale do so by offering simple products such as credit life insurance. Agricultural, asset and health insurance were major beneficiaries of government subsidies, while life products receive most donor subsidies.

\section{Index crop and livestock insurance $^{43}$}

Crop and livestock insurance could reduce climate and disease related farming risks, and perhaps induce farmers to adopt riskier but higher return technologies or enterprises (Cole et al., 2013). It can also reduce risks for FSPs. Index-based insurance raised hopes for a feasible method of reaching smallholders but it is

${ }^{43}$ Parts of this section were drawn from Meyer (2011). 
proving to be complex both to design and gain farmer acceptance. A major disadvantage is that basis risk (the risk that pay-outs may not match farmer losses) makes it difficult for farmers to understand.

An IFAD/World Food Program review of pilot index insurance programs identified key drivers of sustainability and areas for subsidisation (Hazell et al., 2010). Two types of data are often lacking, which complicates creating actuarially sound index insurance. One is time-series weather observations to create the index - generally rainfall and temperature. The second is time-series crop yields or livestock deaths to correlate with weather data. Weather data from satellites has been proposed as an alternative to ground-level weather stations but the concept has not yet been robustly tested (Rosema et al., 2014).

The World Bank identified a fundamental issue with insurance based on its several pilot projects (World Bank, 2011). Agricultural insurance does not fit the general insurance model of sustainability where attractive premiums can be offered because the insured risks occur infrequently to relatively few of the insured, and the insurer's total losses are low. Sustainability suffers because of high dropout rates by farmers who purchase insurance but receive no pay-out due to basis risk. The best potential may be to market it through risk aggregators, such as banks or input suppliers, rather than directly to farmers.

Climate change poses challenges that further complicate the technical issues. Farmers may need to adopt risk reducing practices, which is the objective of a few microinsurance schemes (Baarsch et al., 2013). For example, the Kilimo Salama insurance product was launched by the Syngenta Foundation in 2009 to assist farmers cope with changing weather by insuring agricultural inputs. ${ }^{44}$ Only farmers purchasing droughtresistant hybrid seeds can insure as little as one kilogram of seeds. The large investment for hardware and software, obtaining government approvals and developing relationships with dealers, farmers and others raises questions about long-term viability. ${ }^{45}$

Other recent insurance developments include the creation of the African Risk Capacity agency with the objective of merging disaster relief with concepts of risk pooling and transfer for a sustainable Africa- wide strategy for managing climate risks (ARC, no date). Another initiative is the Agricultural Insurance Development Program created to support countries in implementing sustainable, cost-effective public-private partnerships for agricultural insurance (AIDP, 2013). It will engage in institution building through capacity improvement, policy dialogue, advisory services and knowledge management activities. It will also develop approaches to measure if the benefits derived from insurance justify the subsidies necessary to stimulate uptake and cover costs.

Most of these insurance schemes have not been comprehensively evaluated, so the impacts on participants and their potential commercial sustainability are uncertain. Even if technical issues can be resolved, lack of farmer acceptance and willingness to pay imply it will need to be subsidised as is crop insurance in high income countries. Subsidies generally favour wealthier farm households, thereby eroding poverty objectives, and they rarely work as planned (Skees et al., 2007).

\section{Partial credit guarantees}

Credit guarantee funds are frequently used to induce lending to specific target groups. It is hoped through learning, lenders will become more effective in loan underwriting and lend to the target group without needing guarantees. There are at least three problems with this rationale. First, if reluctance to lend is due to legal and regulatory problems, high rates earned on government securities, or other problems, the first best strategy is to undertake reforms to directly address the problems. Second, the rationale for an international guarantee appears naïve. How can external guarantors, who know little about local conditions faced by lenders, evaluate credit risks better than local lenders? Third, if local lenders think a particular category of borrower, such as small farmers, will likely default, why should they lend if they will lose, perhaps 50 per cent of the losses not covered by guarantees?

Studies beginning in the 1990s have been cautious about expecting significant impacts from guarantees because of little clear evidence of additionality, and many guarantees have not been sustainable without subsidies (Honohan, 2010)..$^{46}$ USAID has conducted several recent evaluations. They reported several

\footnotetext{
${ }^{44}$ By 2013 it had insured close to 200,000 farmers in Kenya, Rwanda and Tanzania. It was converted in 2014 to the Agriculture and Climatic Risk Enterprise Limited (ACRE), and received an investment from Grameen Credit Agricole. It is the first insurance brokerage firm to reach smallholders and pay claims through mobile phone technology (Grameen Credit Agricole, 2015).

${ }^{45}$ See more details in Grossman and Tarazi (2014). See also a discussion of how Kilimo Salama developed a system of pay outs based on weather conditions and data from special weather centres so the service can be automated and verified using low-cost technology for faster market uptake (Pénicaud and Katakam, 2013). Also see comments about sustainability in Stone et al. (2012).

${ }^{46}$ Several studies are also cited in Meyer (2011).
} 
positive impacts but the research methods were too questionable to clearly conclude guarantees 'caused' additionality in lending. USAID guarantees are offered to complement its other development projects, which may be necessary for successful lending in addition to its guarantees (USAID, 2013). Lenders may believe that achieving low default rates requires guarantees combined with other donor programs. ${ }^{47}$ Training on the technology and best practices for sustainable agricultural lending that is provided along with guarantees may have greater impact than the guarantees. Robust evaluations are needed to determine if credit guarantees produce the desired impacts and are worthy of so much donor support.

\section{Warehouse receipts systems $(\mathrm{WRS})^{48}$}

Warehouse receipts are a common method to catalyse agricultural lending by collateralising stored commodities. Additional benefits may include secure places for storage leading to reduced price variations across seasons, and permit farmers to avoid selling immediately at harvest. These systems are not well developed in Africa and are usually used by a few large borrowers, usually importers, under collateral management agreements with international inspection companies. Models funded by donors have often failed because of limited scale economies and policies that damage incentives for storage by importing commodities during grain shortages (Coulter, 2009). The requirements for successful warehouse lending are demanding and cannot be easily met by small farmer associations or cooperatives without considerable outside support. ${ }^{49}$

There are two African examples of village-level warehouse programs designed to avoid the problems of large-scale warehouse management. A rice inventory credit product called 'Grenier commun villageois' is offered by the Caisses d'Épargne et de Crédit Agricole Mutuels de Madagascar (Bouquet et al., 2009). Sixmonth loans allow producers to store harvests until the lean season when market prices are normally higher. It is accessible to small-scale producers because the minimum quantity required for a loan is only 75 kilograms. Storage is provided in local warehouses secured by two locks, one held by the credit officer and another by the warehouse representative. Interest rates are three per cent per month for a minimum of five months. Both rich and poor producers use the storage, but poorer households value it more for consumption smoothing and to forcibly save rice for family consumption.

In Kenya, the Grameen Foundation in collaboration with Farm Concern International is designing an e-warehouse pilot for maize farmers that involves onfarm/group/village-level storage, verification checks involving a special mobile phone application, market price SMS updates and buyer forums to connect to markets (Grameen Foundation, 2014; Grossman and Tarazi, 2014). Village knowledge workers recruit and train farmers to operate the system. Grain can be stored at home, collectively with other farmers or in village-level warehouses. A mobile-based tool is used to upload information about amount, storage method and moisture content, and a GPS device records locations to ensure that data are not remotely invented and that the grain can be tracked. The project prepares loan eligibility information shared with a partner FSP to make credit decisions and disburse loans. Loans cover 50 per cent of the grain's stored value. Four challenges have been identified. One is finding financial institutions willing to commit the required resources. A second is convincing farmers eager for cash at harvest to wait for the e-warehouse processing. Third, ensuring data accuracy is challenging and, fourth, financial sustainability has not yet been determined.

USAID is analysing the use of ICT, including mobile phone and internet services, radio, digital devices, cameras, geographic information systems and handheld computing devices, in WRSs and commodity exchanges (CEXs) (USAID, 2012). The primary use in WRSs and CEXs has been to shift from paper-based to electronic systems, to accommodate 24-hour trading, speed transaction times and reduce back office costs. There has been little analysis in Africa to evaluate if ICT use provides benefits to smallholders or improves the competitiveness of agricultural value chains. Its use is rarely, if ever, a critical factor in establishing sustainable operations; it may even be a distraction from other critical components needed for success. A potential strategy may be to first target the commercial sector (mainly large traders and processors) in order to build up trading volumes needed for sustainability, and then subsidise the incorporation of smallholders.

\footnotetext{
${ }^{47}$ The PASS Trust in Tanzania is an example of a 'guarantee plus' project designed to increase finance for agricultural SMEs. It supports them to develop business plans to present to commercial banks and a credit guarantee is offered to banks to reduce their lending risks. It has been subsidised by Danida for 14 years, is now approaching sustainability and is being tested in neighbouring countries. See Stone et al. (2012).

${ }^{48}$ Parts of this section were drawn from Meyer (2011).

${ }^{49}$ An example in Uganda involving a USAID pilot with the 2100 members is described in Besigye (2009).
} 


\section{Credit scoring}

One of the major impediments to smallholder lending is the high cost of evaluating borrower creditworthiness. Personnel costs are high, especially in Africa where the relationship between personnel costs and small loan sizes is particularly unfavourable. Group lending is less desirable than individual lending, which is better able to adjust loan terms and conditions to the needs and capacities of individual borrowers. However, it is expensive to use 'expert' loan officers to collect and evaluate borrowers and estimate anticipated household cash flows. Experiments with credit scoring are being tested to reduce these information costs.

Scoring is a form of risk assessment based on a statistical analysis of factors expected to affect creditworthiness. The feasibility of scoring was rejected by MFIs more than a decade ago, because it requires electronic data that most did not have for many past loans, client characteristics, loan contracts and rejected applicants (Schreiner, 2003). Even with such data, score cards were not expected to replace loan officer subjective evaluation of risk. Therefore, they relied on subjective judgments to construct score cards (Opportunity International, 2008). They use expert judgment to identify 3-5 factors affecting risk, and then lending policies and pricing decisions are set related to borrower risk profiles. The design and implementation of a system in a Central Africa bank was estimated at US $\$ 11,500$ - the benefits included an increase in productivity, decline in non-performing loans and increased customer satisfaction due to quicker loan decisions (Singh and Venkata, 2013).

Mobile phones create new scoring possibilities. ${ }^{50}$ First Access is designing scoring systems for use by the Musoni MFI in Kenya and other MFIs in Tanzania (First Access, no date). If successful, a loan officer would access a loan applicant's mobile phone records which, combined with other digital data, would produce a credit decision to be shared with the applicant in minutes. InVenture offers a self-reporting financial tracking tool for small businesses along with a credit scoring system designed to assist them to grow and access finance (Inventure, no date). The data inputted by customers is combined with data from mobile money transactions and other sources to produce daily business profit and loss statements and to credit score customers. By combining mobile phone data and repayment data from a credit card company in Brazil, Cignifi successfully created scores to segment and target customers for a new credit product (Cignify, no date). Psychometric data are reportedly being collected in Africa for use in scoring but the only analysis located describes the effectiveness of using African data in a Peruvian MFI (Klinger et al., 2013).

Another scoring application incorporates specialised agricultural information. The Agricultural Loan Evaluation System (Frankfurt School of Finance and Management, 2013) is a model to assess loan applications for agricultural enterprises in Tajikistan, Turkey and Senegal. It calculates the farmer's 'most likely minimum income' based on average production costs. Agricultural data (average yields, selling prices, working capital requirements, production processes and related costs) are used to create 'tech cards'. The costs of up to 30 different crops are inserted into a tool that automatically calculates total working capital requirements and expected yield/income based on the qualitative and quantitative information provided. A summary report suggests loan limits for each type of loan product requested.

The effectiveness and efficiency of these scoring methods have not yet been clearly demonstrated. Using mobile phone and other data, such as P2P and utility bill payments, may be effective with relatively 'data rich' urban microentrepreneurs, but less likely to effectively screen rural populations and especially 'data poor' smallholders. Scoring applications using additional information about farm and farmer characteristics, accessibility to markets and quality of the natural resource base will likely generate better results. The complexity of sophisticated models and the need for skilled people to design and continuously update and improve them slows the development of this innovation.

\footnotetext{
${ }^{50}$ The possible use of digital data in finance is discussed in Kumar and Muhota (2012).
} 


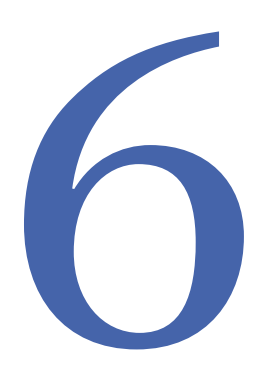

\section{Financial infrastructure}

Financial infrastructure including institutions, information, technologies, rules and standards is the foundation for a modern financial system (World Bank and IFC, 2009). Creating this infrastructure requires investments in public goods that benefit all financial institutions. Such investments may generate a greater return than investments in individual FSPs as occurs in many development projects. This section summarises the role of collateral registries and credit bureaus as key parts of financial infrastructure.

\section{Collateral registries for movable property}

Collateral is expected to make two contributions to lending: it signals that borrowers are serious about repaying and provides a secondary opportunity for lenders to recover part or all of outstanding loans that are defaulted. The value of movable property as collateral is restricted, however, when there are no functioning laws and registries to govern secured transactions. Credit registries can increase access to FSP finance at better interest rates and longer loan maturities, and the effect may be larger for smaller firms (Love et al., 2013). Registries are typically owned and operated by regulatory bodies to collect credit information from regulated FSPs. Their primary objective is to support banking supervision and provide data to regulated FSPs so they can better manage credit risk. Non-regulated institutions, such as MFls and memberowned institutions, can often choose whether or not to participate (Lyman et al., 2011).
Africa's first web-based collateral registry was launched in Ghana in 2010 and allows small-scale entrepreneurs to list movable property as collateral. To date, it is reported to have facilitated financing to more than 9000 SMEs and 30,000 microenterprises. Tanzania opened a credit reference databank for financial institutions to share and access the credit history of individuals and businesses, and 35 banks were submitting data within six months (IFC, 2013). Important design issues for registries include ownership and management of the registries, comprehensiveness, accessibility and financing. ${ }^{51}$

\section{Credit bureaus}

Credit bureaus are expected to improve credit market performance in four ways. First, details about loan applicant characteristics and financing history should improve accuracy in client screening. Second, improvements in informal processes of information exchange about customers should improve FSP loan terms and conditions. Third, borrower discipline may be enhanced when they know that financial information will be shared about them. Finally, client over-indebtedness may be reduced where borrowing from multiple sources occurs (Jappelli and Pagano, 2000).

Credit bureaus merge information about a borrower's credit history to create comprehensive credit history reports, and sometimes credit scores, that are sold to FSPs. Most are privately operated, for-profit entities (Lyman et al., 2011). The costs of submitting data and obtaining reports get passed on to customers directly or

\footnotetext{
${ }^{51}$ The IFC also assisted China to create a national online registry for pledges of receivables for leasing. See an analysis in Stone et al. (2012).
} 
indirectly. Sometimes MFIs create their own databases and share credit histories, and in some markets these have evolved into privately owned and operated credit bureaus. Fifteen sub-Saharan African countries are reported to have private credit bureaus (IFC, no date), but the region lags in several measures of credit information (IFC, 2012a).

There are no evaluations of how African credit bureaus have been designed, the level of participation by FSPs that serve agriculture and the impacts on improving access to financial services. One impact study was located outside the region. An evaluation of a MFIcreated system was conducted for a Guatemalan MFI, and it showed improvements in repayment performance and employee efficiency. The authors concluded that bureaus are relatively low-cost and should be part of financial deepening programs (de Janvry et al., 2010).

An important credit bureau issue is the extent to which coverage includes FSPs that target low-income borrowers. Although 26 sub-Saharan African countries have public credit registries and 13 have private credit bureaus, MFls participate only in Burundi, Mozambique, Rwanda, South Africa, Tanzania and Uganda (CGAP/ MIX, 2011). Three factors may constrain participation. First, the costs may seem prohibitive because many small FSPs are only semi-automated or use manual systems, so upgrades in MIS systems will be needed to compile and submit data. A second design issue concerns the quality and value of credit reports.

Borrowers must be uniquely identified, and the reports produced must be useful, with a minimum of errors, and tailored to the appropriate market segment. Third, FSPs must build awareness among consumers whose data are shared so that building a favourable credit history influences borrower behaviour. The full benefits of credit bureaus may not emerge, therefore, until competition increases among FSPs and borrowing from multiple sources occurs more frequently.

\section{Term finance and land as collateral}

Term finance is generally not available for farmers and agribusinesses in Africa for two major reasons. First, FSPs generally consider it too risky compared to supplying smaller, short-term, working capital loans. Therefore, major long-term investments in large-scale farms, plantations and agribusinesses in traditional sectors, such as bananas, coffee, cotton, sugar and tea, are often financed by foreign investors and financial institutions better able to deal with the risks (Hollinger, 2004). Second, term loans are a special challenge for FSPs because of the potential mismatch in term structure of assets and liabilities. Term lending requires stable long-term savings, which are scarce in most countries. The emergence of private pension systems could provide opportunities in the future for well-managed FSPs to tap long-term funding sources (Ashiagbor et al., 2014).

Leasing can reduce lending risks in countries with weak business environments, particularly with weak creditor rights and collateral laws and registries. Leasing companies are reported to lease agricultural equipment in Brazil and India, but the one African case studied, the Development Finance Company Uganda, had only five per cent of its portfolio in agriculture (IFC, 2012b). ${ }^{52}$

Recent efforts to finance medium-term loans and leases for smaller scale farmers and SMEs in Africa have been largely supported by donors or international agencies. ${ }^{53}$

The issue of secure access to and use of land is a complicated subject, but must be resolved if the rate of agricultural growth and term lending are to increase in Africa. A new report recommends a ten-step strategy to scale up reforms and investments (Byamugisha, 2013). The first element is to improve tenure security over communal lands, which are among the 90 per cent of unregistered rural lands in sub-Saharan Africa (Byamugisha, 2013; page 7). This could have at least three positive impacts. First, the combination of increased foreign direct investment and higher population and economic growth have increased land values and demand for communal lands, and this makes traditional landholders vulnerable to dispossession.

Second, preliminary evidence in Africa finds a positive relationship between tenure security and land-related investments. Third, land with secure tenure is the most valuable collateral for agricultural lending, so improved tenure should improve access to more and lower-cost term loans (Byamugisha, 2013; page 36). For the latter to occur, however, farmers must have greater access to FSPs, and be willing to offer titled land as loan collateral. Social resistance must be addressed because some owners resist offering land as collateral even when land titles are granted. ${ }^{54}$ This makes socially acceptable land reforms both necessary and difficult to achieve.

\footnotetext{
${ }^{52}$ The need for technical support and after-sales services was identified as a serious issue affecting successful leasing in the Southern African Development Community region. See Stone et al. (2012).

${ }^{53} \mathrm{~A}$ proposal was outlined several years ago for medium term lending in Africa but it appears to have never been seriously considered in the region (Binswanger and van den Brink, 2005).

${ }^{54}$ See Boucher et al. (2008) for a model that explains risk rationing by borrowers who choose to not borrow after receiving land titles. For a detailed discussion about why land reforms dating to the 1950s have not resulted in a greater use of land as collateral for loans in Kenya, see Johnson (2004).
} 


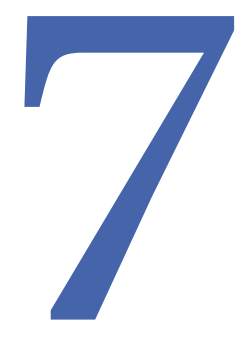

\section{The way forward}

This review summarised a broad set of innovations to improve access to sustainable financial services for agriculture and rural sub-Saharan Africa, along with their strengths and weaknesses. Many focus on credit to reduce the perceived financial constraints of farmers and agribusinesses. Much of the emphasis is narrowly focused on value chains rather than improving access for broader segments of the rural population. Therefore, broad access to financial services is increasing slowly.

Fortunately, innovations have been made in savings that the African population has found to be of great value. In addition, the financial infrastructure has slowly improved, but the benefits for the entire financial system have been slow to materialise. The rate of innovation is faster in East Africa than elsewhere, so the applications must be evaluated to determine the adaptations needed for replication in other countries. Many innovations are still in early stages of design and implementation, so potential limitations and unintended consequences may not yet be obvious. Moreover, many innovations either lack thorough evaluations, or the evaluations lack rigor.

Among the innovations, two are especially dynamic and potentially transformative. They deserve careful expansion and replication. The first is the rapid spread of SGs. The formation of these groups is a low-tech, bottom-up, people-oriented approach to inclusive finance. They are widely accepted by their members as a valued substitute or complement to traditional indigenous informal groups. They facilitate local-level financial intermediation and help establish trust and strengthen governance skills among members. ${ }^{55}$ Once the first $S G$ s are formed in a region by facilitating organisations, they can be multiplied inexpensively by volunteer organisers. Linkages between SGs and FSPs can develop naturally as groups mature and members demand other financial services. As often occurs with MFI group lending, members may eventually prefer to graduate to individual financial products. At this stage, facilitators can play a useful role by assisting mature groups and FSPs to consider linkages, provided that safeguards are created and members given financial education to carefully weigh advantages and disadvantages. The case against linkages is that lacking careful design and implementation, the discipline created through mobilising group savings and balancing the interests of savers and borrowers may be undermined. These attributes may be damaged if linkage projects simply monitor and incentivise number of linkages formed or loans made by FSPs to group members.

SGs are created in most African countries with the aid of NGO and volunteer facilitators, so a three-part assessment is necessary in each country to develop policies and projects for moving forward. First, the progress made in forming SGs, the impacts achieved and their capacity for effectively managing linkage relationships need to be evaluated. One key question is whether men can benefit from SGs when most groups are women-only. Second, FSPs need to be surveyed to determine possible candidates for linkages and their willingness to create appropriate products and polices. Barriers need to be identified, such as lack of mobile phones and charging facilities, expertise on how to use them and high transaction costs in

${ }^{55}$ Evaluations show mixed results on the extent to which SGs create social capital so there are spill-over effects onto other local development activities. See Ashe and Jagger Neilan (2014). 
accessing agents and FSPs in areas where they are few. ${ }^{56}$ Third, SG facilitators and candidate FSPs must jointly develop plans for linkage procedures and products, financial education for members and reducing bottlenecks. ${ }^{57}$ These will be time-consuming steps and will require adequate funding and commitment from all parties involved.

The second notable innovation is the rapidly expanding use of ICTs in finance in Africa, and especially the creative explosion in mobile phone applications. This is a high-tech, top-down revolution in which telecoms, FSPs and governmental and international agencies are testing applications to determine which best meet their objectives. The use of these technologies for financial services is in early stages so the full potential, impacts and unexpected consequences are yet unknown.

Several tasks must be undertaken to identify what is required to advance these innovations. The first is to analyse why East Africa has advanced so rapidly compared to other regions. Possible explanations may be number and mix of mobile phone providers, the nature of competition and cooperation between telecoms and FSPs, population density and level of poverty, number of rural to urban migrants sending money home, societal openness to new technology and the regulatory environment for telecoms and FSPs. Constraints must be identified in each country along with plans to reduce them.

Second, there is much to learn about the formal products and services rural people desire to meet their financial needs in addition to the informal sources already available. To date, users in urban areas have benefitted the most and providers have assumed a natural expansion from urban to rural areas but there has been little investment to understand rural areas and design products accordingly. It is not obvious that using mobile money for money transfers and remittances will significantly reduce barriers to other financial services in rural areas with few agents and FSPs. It is possible a two-tiered financial system will emerge: one composed of higher income urban users who benefit from both digital finance and financial services supplied in traditional forms from FSPs, while in rural areas some financial needs will be served by digital finance but others will not because of the limited availability of agents or FSPs.

Third, the innovation of digital data for credit scoring is an interesting possibility to reduce information problems for FSPs supplying credit and insurance. It may improve access for data-rich urban mobile users, but have limited relevance for data-poor rural users unless the designers incorporate indicators to predict smallholder creditworthiness. Digital information needs to flow from telecoms to FSPs so users can access financial services. In addition, people develop reputation capital by using local informal financial products such as participating in SGs. To increase financial inclusion, FSPs must find methods to incorporate reputational capital into their decision making because it is not easily captured in credit scoring or by credit bureaus.

Fourth, and finally, the potential benefits derived from many digital applications seem obvious and may prove to be important drivers of financial inclusion. But digital financial services pose risks as well as benefits for FSPs and their clients. ${ }^{58}$ The recent use and abuse of mobile phone and other digital data by businesses, governmental agencies and cybercriminals in developed countries vividly demonstrate issues that developing nations must also consider going forward. Unless they are satisfactorily resolved, they will dampen the use of these tools in finance.

\footnotetext{
${ }^{56}$ An exploratory study of 500 group members in Africa identified several barriers encountered by members in SGs with linkages to FSPs (The MasterCard Foundation, 2014)

${ }^{57}$ In a recent SEEP webinar, CARE discussed how it developed linkages of SGs with banks in Kenya and Tanzania. A formal partnership was established with Equity Bank and the mobile communications firm Orange, and together they developed infrastructure with bank branches, mini-branches and MNO agents. A grant from UNCDF and the Gates Foundation subsidised some of the costs of setting up the system, SEEP's webinar, 10 December 2014 (SEEP, 2014 ), SGs and mobile banking: CARE's experience in Kenya and Tanzania (CARE, 2013).

${ }^{58}$ Several risks for MFIs were identified in Digital Financial Services Working Group (2014).
} 


\section{References}

Adams, DW and Fitchett DA (1992) Informal finance in low-income countries. Westview Press, Boulder.

Adams, DW et al. (eds) (1984) Undermining rural development with cheap credit. Westview Special Studies in Social, Political, and Economic Development. Westview Press, Boulder.

AFI (Alliance for Financial Inclusion) (no date) www. afi-global.org, accessed 18 August 2014.

AgDevCo (no date) www.agdevco.com, accessed 5 December 2014.

AgriFin (no date) www.agrifinfacility.org/bancooportunidade-de-mozambique-bom-project-results-andlessons

AIDP (Agricultural Insurance Development Program) (2013) http://siteresources.worldbank.org/

FINANCIALSECTOR/Resources/AIDPStrategyNote donors_15Apr13.pdf, accessed 5 August 2014

Ajai, N and Fissha, A (2012) Rural banking: the case of rural and community banks in Ghana. Agriculture and Rural Development Discussion Paper 48. World Bank, Washington DC. www.ruralfinance.org/fileadmin/ templates/rflc/documents/Rural__Banking__1_pdf.pdf

Aker, JC (2010) Information from markets near and far: mobile phones and agricultural markets in Niger. American Economic Journal: Applied Economics 2(July 2010) 46-59. www.aeaweb.org/articles. php?doi=10.1257/app.2.3.46

Aker, JC et al. (2012) Can mobile phones improve learning? Evidence from a field experiment in Niger. American Economic Journal: Applied Economics 4(4) 94-120.

Allan, A et al. (2013) Banking on change: breaking barriers to financial inclusion. Banking on Change Partnership, London. www.microfinancegateway. org/sites/default/files/mfg-en-case-study-bankingon-change-breaking-barriers-to-financial-inclusionjan-2013.pdf

Allen, $\mathrm{H}$ (2010) Why I think that community-managed microfinance programmes should be careful about borrowing from banks. In: Wilson, $\mathrm{K}$ et al. (eds). Financial Promise for the Poor: How Groups Build Microsavings. Kumarian Press, Sterling, VA. http:// savings-revolution.org/doclib
Arabehety, PG (19 September 2013) More on why OTC makes sense for Kenya. CGAP blog. www.cgap. org/blog/more-why-otc-makes-sense-kenya

ARC (African Risk Capacity) (no date) www. africanriskcapacity.org/, accessed 5 August 2014.

Ardic, OP et al. (2013) Financial Access 2012: Getting to a more comprehensive picture. Access to Finance Forum, Reports by CGAP and Its Partners, No. 6. www. cgap.org/sites/default/files/cgap_forum_FAS2012.pdf

Ashe, J and Jagger Neilan, K (2014) In their own hands: how savings groups are revolutionizing development. Berrett-Koehler Publishing, San Francisco.

Ashiagbor, D et al. (2014) Pension funds and private equity: unlocking Africa's potential. Commonwealth Secretariat, London. www.mfw4a.org/nc/knowledgecenter/resources/documents/documents-details/file/ pension-funds-and-private-equity-unlocking-africaspotential-2014.html

Athmer, G and Bosch, E (2013) Policy guidelines for donor support to member-owned financial institutions in rural Sub-Saharan Africa: focus on savings groups and financial cooperatives. NpM, Platform for Inclusive Finance. www.fgda.org/dati/ContentManager/files/ Documenti_microfinanza/Policy-guidelines-for-donorsupport-to-member-owned-FI-in-rural-sub-saharanAfrica.pdf

Baarsch, F et al. (2013) Changing climate - changing behaviour: How agricultural microinsurance can help smallholders reduce their risk of climate-related disaster. Working Paper 02, endeva UG, Berlin, Germany. http:// businessinnovationfacility.org/profiles/blogs/changingclimate-changing-behaviour-how-agricultural. www. climateanalytics.org/sites/default/files/attachments/ publications/Baarsch et al 2013 MI_DRR_reviewpaper. pdf

Banerjee, A et al. (2014) Bundling health insurance and microfinance in India. Research paper no. 37. Microinsurance Innovation Facility, International Labour Office, Geneva. www.microinsurancefacility.org/ publications/rp37

Banerjee, A et al. (2015) Six randomized evaluations of microcredit: introduction and further steps. American Economic Journal: Applied Economics 7(1) 1-21. 
Bankable Frontier Associates (2014a) Focus Note 1: Outcompeting the Lockbox - Linking Savings Groups to the Formal Financial Sector. Somerville, MA. http:// bankablefrontier.com/wp-content/uploads/documents/ BFA-Savings-Group-Linkages-Focus-Note-1.pdf

Bankable Frontier Associates (2014b) Focus Note 2: SG Linkages - The Business case for Private Service Providers. Somerville, MA. http://bankablefrontier.com/ wp-content/uploads/documents/BFA-Savings-GroupLinkages-Focus-Note-2.pdf

Beaman, L et al. (2014) Saving for a (not so) rainy day: a randomized evaluation of savings groups in Mali. NBER Working Paper 20600. Cambridge, MA. www.nber.org/ papers/w20600

Besigye, A (2009) Financial institutions client perspectives from Kapchorwa. In: Roberts, R and Ocaya, R (eds) Agriculture Finance Year Book 2008. Bank of Uganda/GTZ-Sida Financial Systems Development Program, Kampala, 59-62. www. agrifinfacility.org/sites/agrifinfacility.org/files/ Agricultural Finance\%20Yearbook\%202008\%20-\%20 Uganda\%20-\%20GTZ\%20etc_0.pdf

Besley, T (1994) How do market failures justify interventions in rural credit markets? World Bank Research Observer 9(1) 27-47, 1994. www-wds. worldbank.org/external/default/WDSContentServer/ WDSP/IB/1999/09/30/000178830_9810191145179 0/Rendered/PDF/multi_page.pdf

Binswanger, HP and Khandker, SR (1995) The impact of formal finance on the rural economy of India. The Journal of Development Studies 32(2) 234-262.

Binswanger, HP and Rosenzweig, MR (1986) Behavioural and material determinants of production relations in agriculture. The Journal of Development Studies 2(3) 503-39. http://econweb.econ.kuleuven. ac.be/licos/events/200711scottrozelle/Day_1/rosen_ binswanger.pdf

Binswanger, HP and van den Brink, R (2005) Credit for small farmers in Africa revisited: pathologies and remedies. Savings and Development 29(3) 275-292. www.jstor.org/discover/10.2307/25830900?sid =2110 5042572661 \&uid $=2 \&$ uid $=4 \&$ uid $=3739840$ \&uid $=212$ 9 \&uid $=70$ \&uid $=3739256$

Binswanger, HP et al. (1993) How infrastructure and financial institutions affect agricultural output and investment in India. Journal of Development Economics 41(2) 337-366. www.sciencedirect.com/science/ article/pii/030438789390062R

Boucher, S et al. (2008) Risk rationing and wealth effects in credit markets: theory and implications for agricultural development. American Journal of Agricultural Economics 90(2) 409-423. http://ssrn. com/abstract $=1119007$ or http://dx.doi.org/10.1111/ j.1467-8276.2007.01116.x

Bouquet, E et al. (2009) Rice inventory credit in Madagascar: conditions of access and diversity of rationales around a hybrid financial and marketing service. Paper presented at the First European Research Conference on Microfinance, Brussels, June 2-4, 2009. www.ruralfinance.org/fileadmin/templates/ rflc/documents/pdf_WP6.pdf

BRAC (no date) www.brac.net/content/bracbangladesh

Branch, B and Klaehn, J (2002) The keys to striking the balance: an introduction to savings mobilization. In: Branch, B and Klaehn, J (eds) Striking the Balance in Microfinance: A Practical Guide to Mobilizing Savings. World Council of Credit Unions, Madison, WI, 1-28. www.woccu.org/documents/Ch_1

Burgess, R and Pande, R (2005) Do rural banks matter? Evidence from the Indian social banking experiment. The American Economic Review 95(3) 780-795. http://papers.ssrn.com/Sol3/papers. cfm?abstract_id=1127009

Byamugisha, FFK (2013) Securing Africa's land for shared prosperity: a program to scale up reforms and investments. World Bank, Washington DC. https:// openknowledge.worldbank.org/bitstream/handle /10986/13837/780850PUBOEPIOOLIC00pubda te05024013.pdf

CABFIN (2014) Innovaciones en finanzas agropecuarias: hacia una mayor inclusión de hogares rurales dependientes de la agricultura. Taller organizado por FAO y la Alianza CABFIN, $17^{\text {a }}$ Cumbre de Microcrédito, 3 de Septiembre 2014, Mérida, México. www.slideshare.net/Microcredit/innovations-inagricultural-finance

CARE (22 October 2013) www.care.org/work/ economic-development/microfinance/caresmicrofinance-work

Care International in Kenya (2013) Kenya: Linking the cash box to the bank-formal banking of savings groups through mobile money. Access Africa Technical Learning Series: No. 5. Atlanta, GA. www.care.org/ sites/default/files/documents/MF-2013-TechnicalLearning-Series-Publication-Formal-banking-withMobile-Money-Kenya.pdf

CFI (Center for Financial Inclusion) (no date) www. centerforfinancialinclusion.org, accessed 18 August 2014.

CGAP blog (19 November 2014) Four mobile money trends from the IMF Financial Access Survey. www. cgap.org/blog/four-mobile-money-trends-imf-financialaccess-survey 
CGAP/MIX (2011) MIX Microfinance World:

Sub-Saharan Africa Microfinance Analysis and Benchmarking Report 2010. Washington DC. www. themix.org/sites/default/files/096_MIX_Africa Report_05-05-2011.pdf

Chopra, C and Wright, GAN (2011) Financial inclusion through E/M-banking: a guided tour ... linked to resources. MicroSave, New Delhi. www.microsave.net/ files/pdf/Financial_Inclusion_Through_E_M_Banking. pdf

Christen, RP and Anderson, J (2013) Segmentation of smallholder households: meeting the range of financial needs in agricultural families. CGAP Focus Note 85. CGAP, Washington DC. www.microfinancegateway. org/library/segmentation-smallholder-householdsmeeting-range-financial-needs-agricultural-families

Cignify (no date) www.cignifi.com/en-us/technology/ case-study

Cole, $\mathrm{S}$ et al. (2013) How does risk management influence production decisions? Evidence from a field experiment. Harvard Business School Working Paper, No. 13-080. Boston, MA. http://nrs.harvard.edu/urn3:HUL.InstRepos:10647828

Collins, D et al. (2009) Portfolios of the poor: how the world's poor live on $\$ 2$ a day. Princeton University Press, Princeton.

Coulter, J (2009) Review of warehouse receipt system and inventory credit initiatives in Eastern and Southern Africa. A working document for comment commissioned by the United Nations Conference on Trade and Development (UNCTAD), under the All ACP Agricultura Commodities Programme (AAACP). www.ruralfinance. org/fileadmin/templates/rflc/documents/Review__of__ Warehouse_pdf.pdf

CSAF (Council on Smallholder Agricultural Finance) (no date) www.csaf.net/about, accessed 2 August 2014.

Cuevas, CE and Fischer, KP (2006) Cooperative financial institutions: issues in governance, regulation, and supervision. Working Paper no. 82. World Bank, Washington DC. http://elibrary.worldbank.org/doi/ book/10.1596/978-0-8213-6684-4

Cull, $R$ et al. (2014) Benchmarking the financial performance, growth, and outreach of greenfield microfinance institutions in sub-Saharan Africa. Policy Research Working Paper no. 7029. World Bank, Washington DC. http://econ.worldbank.org/external/ default $/$ main?page $P K=64165259$ \& theSitePK $=469$ $372 \&$ piPK $=64165421 \&$ menuPK $=64166093$ \&entity $I D=000158349 \_20140915084416$

Dalberg Group (2012) Catalyzing smallholder agricultural finance. Dalberg Global Development Advisors. http://dalberg.com/documents/Catalyzing_ Smallholder_Ag_Finance.pdf
De Bruyne, B (October 2014) Experience of AMTmembers with rural finance, ADA and African Microfinance Transparency. To be posted at www.amtforum.org

de Janvry, A et al. (2010) The supply- and demandside impacts of credit market information. Journal of Development Economics 93 173-188.

de Montesquiou, A et al. (2014) From extreme poverty to sustainable livelihoods: a technical guide to the graduation approach. CGAP and the Ford Foundation, Washington DC. www.microfinancegateway.org/library/ extreme-poverty-sustainable-livelihoods-technical-guidegraduation-approach

Dermish, A (2011) Branchless and mobile banking solutions for the poor: a survey of the literature. Innovations: Technology, Governance, Globalization 6(4) 81-98. http://papers.ssrn.com/sol3/papers. cfm?abstract_id $=1745967$

Develtere, $\mathrm{P}$ et al. (eds) (2008) Cooperating out of poverty: the renaissance of the African cooperative movement. International Labour Organization, Geneva. http://labordoc.ilo.org/record/412725

Digital Financial Services Working Group (2014) Digital financial services risk assessment for microfinance institutions: a pocket guide. Washington DC. www. microfinancegateway.org/library/digital-financialservices-risk-assessment-microfinance-institutionspocket-guide

Doran, A et al. (2009) The missing middle in agricultural finance: relieving the capital constraint on smallholder groups and other agricultural SMEs. Oxfam GB Research Report. Oxford, UK. www.oxfam.org.uk/ resources/policy/trade/missing-middleagriculturalfinance.html

Dunn, E (2014) Smallholders and inclusive growth in agricultural value chains. Field Report No. 18. USAID, Washington DC. www.microlinks.org/sites/default/files/ resource/files/FIELD\%20Report\%20No\%2018\%20 Smallholders\%20in\%20Value\%20Chains_0.pdf

Earne, J et al. (2014) Greenfield MFls in subSaharan Africa: a business model for advancing access to finance. Forum, Washington DC; CGAP and IFC. www.ifc.org/wps/wcm/connect/ b9813e8042e3dcce80a3ec384c61d9f7/CGAPIFC+Forum\%238+GF+Study.pdf?MOD=AJPERES

e-MFP (2011) www.microfinancegateway.org/sites/ default/files/mfg-en-paper-how-to-support-valuechain-finance-in-a-smart-way-policy-statement-ofthe-european-microfinance-platform-rural-outreachinnovation-action-group-jun-2011.pdf

First Access (no date) www.firstaccessmarket.com 
Fotabong, LA (2012) The microfinance market of Cameroon: analyzing trends and current developments. www.microfinancegateway.org/sites/default/files/ mfg-en-paper-the-microfinance-market-of-cameroonanalyzing-trends-and-current-developments-mar-2012. pdf

Frankfurt School of Finance \& Management (2013) Credit scoring for agriculture lending, Frankfurt, Germany. www.agrifinfacility.org/sites/agrifinfacility. org/files/Dakota\%20Dobyns/385/AgriFin\%20Sri\%20 Lanka\%20Conference,\%20Frankfurt\%20School\%20 03.08.2013.pdf

Frydrych, J and Aschim, H (2014) Extending reach: mobile money in rural areas; findings based on the State of the Industry Report. GSMA Mobile Money for the Unbanked, London. www. gsma.com/mobilefordevelopment/wp-content/ uploads/2014/10/2014_DI_Extending-reach_Mobilemoney-in-rural-areas.pdf

Gallardo, J et al. (2006) Strategic alliances to scale up financial services in rural areas. World Bank Working Paper No. 76. Washington DC. http://econ.worldbank. org/external/default/main?pagePK $=64165259 \&$ theSite $\mathrm{PK}=478060$ \& $\mathrm{piPK}=64165421 \& \mathrm{menuPK}=64166093 \&$ entity $I D=000012009 \_20060421144415$

Gameli Djokoto, J et al. (2014) Domestic and foreign direct investment in Ghanaian agriculture. Agricultural Finance Review 74(3) 427-440.

Gash, M and Odell, K (2013) The evidence-based story of savings groups: a synthesis of seven randomized control trials. The SEEP Network, Arlington, VA. www. microfinancegateway.org/library/evidence-based-storysavings-groups-synthesis-seven-randomized-controltrials

Global Development Incubator (no date) www. globaldevincubator.org/initiative-incubator/currentinitiatives/initiative-for-smallholder-finance, accessed 2 August 2014.

Grameen Credit Agricole (January 2015) www. grameen-credit-agricole.org/sites/grameen/files/ newsletter_sept_14_janv_15_an.pdf

Grameen Foundation (2014) Facilitating access to finance and markets: an e-warehouse pilot for Kenyan farmers. Presentation slides, Unlocking Smallholder Assets: Warehouse Receipts and ICT, USAID webinar, 28 May 2014. http://agrilinks.org/sites/default/files/ resource/files/ASC Webinar May 2014.pdf

Grameen Foundation (no date) www. grameenfoundation.org/press-releases/airtel-ugandagrameen-foundation-and-plan-uganda-introduce-newgroup-savings-produc-2
Grossman, J and Tarazi, M (2014) Serving smallholder farmers: recent developments in digital finance. Focus Note 94. CGAP, Washington DC. www.cgap.org/ publications/serving-smallholder-farmers-recentdevelopments-digital-finance

GSMA (no date) www.gsma.com/ mobilefordevelopment/paying-taxes-throughmobile-money-initial-insights-into-p2g-and-b2gpayments?utm_medium =social-media\&utm_ campaign $=$ mmu041214\&utm_source $=$ twitter

Hammond, A, Technology trends that will drive base of the pyramid financial services: Why telecoms, not banks, are the key to the future, pp. 204-210 in Napier, M (ed.) Real Money, New Frontiers: Case Studies of Financial Innovation in Africa. Juta and Company Ltd, Claremont, South Africa.

Hazell, P et al. (2010) Potential for scale and sustainability in weather index insurance for agriculture and rural livelihoods. International Fund for Agricultural Development and World Food Programme, Rome. www.ifad.org/ruralfinance/pub/weather.pdf

Hollinger, F (2004) Financing agricultural term investments. Agricultural Finance Revisited No. 7. FAO, Rome. www.fao.org/docrep/008/y5565e/y5565e00. htm

Honohan, P (2010) Partial credit guarantees: principles and practice. Journal of Financial Stability 6(1) 1-9.

Honohan, $P$ and Beck, $T$ (2007) Making finance work for Africa. World Bank, Washington DC. www.mfw4a. org/fileadmin/data_storage/documents/other-internaldocuments/Making_Finance_Work_for_Africa.pdf

Homestrings (no date) www.homestrings.com

IFC (International Finance Corporation) (2012a) Credit reporting knowledge guide. Washington DC. www. ifc.org/wps/wcm/connect/industry_ext_content/ifc_ external_corporate_site/industries/financial+markets/ publications/toolkits/credit+reporting+knowledge+gu ide

IFC (2012b) Innovative agricultural SME finance models. Washington DC. http://www.ifc.org/wps/wcm/ connect/55301b804ebc5f379f86bf45b400a808/ Innovative+Agricultural+SME+Finance+Models. pdf?MOD $=$ AJPERES

IFC (2013) Access to finance sub-Saharan Africa, Fiscal Year 2013. Washington DC. http://www.ifc. org/wps/wcm/connect/industry_ext_content/ifc_ external_corporate_site/industries/financial+markets/ publications/access+to+finance+sub-saharan+africa 
IFC (2014) Access to finance for smallholder farmers: learning from the experiences of microfinance institutions in Latin America. Washington DC. http:// www.ifc.org/wps/wcm/connect/071dd78045eadb5c b067b99916182e35/A2F+for+Smallholder+FarmersFinal+English+Publication.pdf?MOD=AJPERES

IFC (no date) Credit bureaus around the world. http://www.ifc.org/wps/wcm/connect/098f18004f6 4d0838050ee0098cb14b9/Private+Credit+Burea us+Around+the+World+J13.pdf?MOD=AJPERES, accessed 21 August 2014.

IMTFI (no date) http://blog.imtfi.uci.edu/2014/11/ lessons-from-field-m-shwari-and-jua.html

infoDev (Information for Development Program)/The World Bank (2013) Crowdfunding's potential for the developing world. World Bank, Washington DC. www. infodev.org/infodev-files/wb_crowdfundingreport-v12. pdf

Inventure (no date) www.inventure.org/downloads/ inventureproducts_scoring.pdf

Jain, A et al. (2014) A progressive approach to financial inclusion. MasterCard Advisors, New York. www.mastercardadvisors.com/financialinclusion/ MasterCardAdvisors_Financial_Inclusion_2014.pdf

Jappelli, T and Pagano, M (2000) Information sharing in credit markets: a survey. Working paper number 36. Centre for Studies of Economics and Finance, Università Degli Studi di Salerno, Italy. http://www. ecri.be/new/system/files/7+jappelli_pagano_credit bureaus.pdf

Johnson, S (2004) 'Milking the elephant': financial markets as real markets in Kenya. Development and Change 35(2) 247-274. www.ualberta. ca/ agchiu/12787285.pdf

Johnson, S and Nino-Zarazua, M (2011) Financial access and exclusion in Kenya and Uganda. The Journal of Development Studies 47(3) 475-496. http://opus. bath.ac.uk/20008/1/Johnson_JDV_2011_47_3_475. pdf

Jones, $\mathrm{H}$ et al. (2000) Linking formal and informal financial intermediaries in Ghana: conditions for success and implications for RNR development. Natural Resource Perspectives, Number 61. ODI, London. www.odi.org/sites/odi.org.uk/files/odi-assets/ publications-opinion-files/2835.pdf

Kalanda, AA and Campbell, B (2008) Banking rollout approaches to rural markets: Opportunity International Bank of Malawi. White Paper No. 8. Opportunity International, Oak Brook, Illinois. http://opportunity. org/content/News/Publications/Knowledge $\% 20$ Exchange/Banking\%20Rollout\%20Approaches\%20 to $\% 20$ Rural $\% 20$ Markets $\% 200$ pportunity $\% 20$ International\%20Bank\%20of\%20Malawi.pdf
Karlan, D (2014) The next stage of financial inclusion. Stanford Social Innovation Review Fall 2014 42-49. www.ssireview.org/pdf/Fall_2014_The_Next_Stage_ of_Financial_Inclusion_1.pdf

Klinger, B et al. (2013) Improving credit risk analysis with psychometrics in Peru. Technical Note No. IDB-TN-587. Inter-American Development Bank, Washington DC. http://publications.iadb.org/bitstream/ handle/11319/5999/Improving\%20Credit\%20 Risk\%20Analysis\%20with\%20Psychometrics\%20 in\%20Peru\%20FINAL.pdf;jsessionid=ABE8D 955257 7B6B78860CA6A0FADD5B6? sequence $=1$

Kumar, K and Muhota, K (2012) Can digital footprints lead to greater financial inclusion? CGAP Brief, Washington DC. www.cgap.org/sites/default/files/ CGAP-Brief-Can-Digital-Footprints-Lead-to-GreaterFinancial-Inclusion-Jul-2012.pdf

Linkedln Pulse (21 December 2014) www.linkedin. com/pulse/big-idea-2015-when-impact-investing-meetsdeepak-mehra

Love, I et al. (2013) Collateral registries for movable assets: does their introduction spur firms' access to bank finance? World Bank Policy Research Working Paper 6477. Washington DC. http://elibrary.worldbank. org/doi/pdf/10.1596/1813-9450-6477

Luoto, J et al. (2007) Credit information systems in less developed countries: a test with microfinance in Guatemala. Economic Development and Cultural Change 55(2) 313-334. www.microfinancegateway. org/library/credit-information-systems-less-developedcountries-test-microfinance-guatemala

Lyman, T et al. (2011) Credit reporting at the base of the pyramid: key issues and success factors. FORUM 1. Washington DC, CGAP and IFC. www.cgap.org/sites/ default/files/CGAP-Forum-Credit-Reporting-at-theBase-of-the-Pyramid-Oct-2011.pdf

McCaffrey, M et al. (2014) Agent Network Accelerator Survey: Kenya Country Report 2013. Shelter Afrique House, Nairobi, Kenya. http://helix-institute.com/sites/ default/files/Publications/Agent $\% 20$ Network\%20 Accelerator_Kenya\%20Country\%20Report_2013.pdf

Meyer, RL (2011) Subsidies as an instrument in agriculture finance: a review. Joint Discussion Paper, German Federal Ministry of Economic Cooperation and Development (BMZ), Food and Agriculture Organization of the United Nations (FAO), German Agency for International Cooperation (GIZ), International Fund for Agriculture Development (IFAD), The World Bank, and United Nations Capital Development Fund (UNCDF), World Bank, Washington DC. http://siteresources. worldbank.org/INTARD/Resources/Subsidies_as_ Intrument_AgFin.pdf 
Meyer, RL (2014) Innovative microfinance: potential for serving rural markets sustainably. In: Köhn, D (ed.) Finance for Food: Towards New Agricultural and Rural Finance. Springer, Heidelberg, New York, Dordrecht, London. http://rd.springer.com/book/10.1007/978-3642-54034-9

Meyer, RL et al. (2004) Agricultural finance in Uganda: the way forward. Financial System Development Programme, Kampala www.ruralfinance.org/library/ policy-advice/agricultural-finance/agricultural-financedetails/en/?srec $=10711 \&$ tdet $=$ training\&tdet $3=2$

Miller, C and Jones, L (2010) Agricultural value chain finance: tools and lessons. Practical Action Publishing, Warwickshire, UK.

Miller, $\mathrm{C}$ et al. (in press) Agricultural investment funds as innovative vehicles for private-public investment collaboration. FAO, Rome.

MIX (no date) www.themix.org

MIX Market (2013) 2012 Sub-Saharan Africa

Regional Snapshot. www.slideshare.net/fullscreen/

MIXdsheth/2012-subsaharan-africa-regional-snapshot/1

MIX Market (no date) www.mixmarket.org/mfi/region/ Africa, accessed 25 August 2014

Muto, M and Yamano, T (2009) The impact of mobile phone coverage expansion on market participation: panel data evidence from Uganda. World Development 37(12) 1887-1896.

Napier, M (ed.) (2010) Real money, new frontiers: case studies of financial innovation in Africa. Juta and Company Ltd, Claremont, South Africa.

One Acre Fund (no date) www.oneacrefund.org/, accessed 21 November 2014.

Opportunity International (2008) Credit scoring in microfinance. White Paper No. 9. Oak Brook, Illinois. www.opportunity.net/files/Credit\%20Scoring $\% 20$ White\%20Paper\%20-\%20FINAL\%20formatted.pdf

Pagura, M and Kirsten, M (2006) Formal-informal financial linkages: lessons from developing countries. Small Enterprise Development 17(1) 16-29.

Pénicaud, C and Katakam, A (2013) State of the industry 2013: mobile financial services for the unbanked. GSMA, London. www.gsma.com/ mobilefordevelopment/wp-content/uploads/2014/02/ SOTIR_2013.pdf
Porteous, D (2014) Mobile financial services in Africa: the next generation. In: Beck, T and Munzele Maimbo, S (eds) Financial Sector Development in Africa: Opportunities and Challenges. World Bank, Washington DC, 41-82. https://openknowledge.worldbank.org/ bitstream/handle/10986/11881/9780821396285. pdf?sequence $=2$

Radcliffe, D and Voorhies, R (2012) A digital pathway to financial inclusion. Bill \& Melinda Gates Foundation. http://ssrn.com/abstract=2186926 or http://dx.doi. org/10.2139/ssrn.2186926

Raymond, S (19 December 2014) Boon for the base: crowdfunding for the base of the pyramid. CGAP blog. www.cgap.org/blog/boon-base-crowdfunding-basepyramid

Riquet, C and Debuchy, G (12 January 2015) When digital meets traditional banking: a new concept in Senegal. CGAP blog. www.cgap.org/blog/when-digitalmeets-traditional-banking-new-concept-senegal

Rosema, A et al. (2014) FESA micro-insurance: crop insurance reaching every farmer in Africa. Scientific Final Report of Millennium Agreements Project no. 38. Commissioned by the Netherlands Ministry of Foreign Affairs, Directorate Sustainable Economic Development (DDE), Prepared and published by EARS Earth Environment Monitoring BV, Delft, The Netherlands. www.microfinancegateway.org/library/fesa-microinsurance-crop-insurance-reaching-every-farmer-africa

Root Capital (no date) www.rootcapital.org, accessed 5 December 2014.

Sanford, C (2013) Do agents improve financial inclusion? Evidence from a national survey in Brazil. Bankable Frontier's Associates, Somerville, MA. http:// bankablefrontier.com/wp-content/uploads/documents/ BFA-Focus-Note-Do-agents-improve-financial-inclusionBrazil.pdf

SASRA (SACCO Societies Regulatory Authority) (2012) Sacco Supervision Annual Report 2012. Nairobi, Kenya. www.sasra.go.ke

SAVIX (no date) www.thesavix.org

Schreiner, M (2003) Scoring: the next breakthrough in microcredit? CGAP Occasional Paper No. 7, Washington DC. www.cgap.org/sites/default/ files/CGAP-Occasional-Paper-Scoring-The-NextBreakthrough-in-Microcredit-Jan-2003.pdf

SEEP (10 December 2014) SGs and mobile banking: CARE's experience in Kenya and Tanzania. http://www. seepnetwork.org 
Seibel, HD (2000) Agricultural development banks: close them or reform them? Finance and Development 37(2). www.imf.org/external/pubs/ft/fandd/2000/06/ seibel.htm and Seibel, HD et al. (2004) Reforming agricultural banks. GTZ, Eschborn, Germany. http:// hf.uni-koeln.de/data/aef/File/PDF/AgDB\%20 Reform\%20Strategies/Reforming\%20AgDBs $\% 20$ (Seibel,\%20Giehler,\%20Karduck\%202004).pdf

Sharma, D and Nagarajan, G (2011) Rural finance outreach in central Malawi: implications for Opportunity International Bank of Malawi. IRIS Center, University of Maryland, College Park, MD. www. microfinancegateway.org/library/rural-finance-outreachcentral-malawi-implications-opportunity-internationalbank-malawi

Silici, L and Locke, A (2013) Private equity investments and agricultural development in Africa: opportunities and challenges. Working Paper 62. Future Agricultures Consortium Secretariat at the University of Sussex, Brighton, UK. www. future-agricultures.org/index.php?option $=\mathrm{com}_{\text {_ }}$ docman\&view $=$ download\&alias $=1740$-private-equityinvestments-and-agricultural-development-in-africaopportunities-and-challenges\&category_slug=workingpapers\&ltemid $=1056$

Simtowe, F et al. (2006) Determinants of moral hazard in microfinance: empirical evidence from joint liability lending programs in Malawi. African Review of Money Finance and Banking 2006 5-38.

Singh, A and Venkata, NA (2013) Design considerations for credit scorecard for MSME financing. MicroSave Briefing Note No. 143. Lucknow, India. www.microsave. net/files/pdf/BN_143_Design_Considerations_for_ Credit_Scorecard_for_MSME_Financing.pdf

Skees, J et al. (2007) Scaling up index insurance: what is needed for the next big step forward? Report prepared for Kreditanstalt für Wiederaufbau (KfW), German Financial Cooperation, Frankfurt, Germany. http://globalagrisk.com/Pubs/2007_Skeesetal_ Scaling\%20UP\%20Index\%2OInsurance_KfW_dec.pdf

Stone, $R$ et al. (2012) Study of African and international innovations and best practices in increasing access to rural and agricultural finance. Oxford Policy Management, Oxford, UK. www.opml.co.uk/sites/ default/files/Agrifinance-innovations-final-report.pdf

The MasterCard Foundation (2014) Practices and possibilities in savings groups. Brief. Toronto, Canada. www.mastercardfdn.org/savingsbrief

Thom, M et al. (2014) Scale: thinking big. Microinsurance Paper No. 30. Microinsurance Innovation Facility, Geneva. www.microinsurancefacility. org/sites/default/files/mp30\%20v3.pdf
Trade and Export Finance (2014) Revisiting agricultural finance: a special report from the Fin $4 \mathrm{Ag}$ conference. http://publications.cta.int/media/publications/ downloads/1765_PDF_PUFrkD7.pdf

UNCDF (no date) www.uncdf.org/en/content/mobilemoney-poor-expanded-enable-millions-more-peopleafrica-access-financial-services

USAID (2011) Rural and agricultural finance: taking stock of five years of innovations. microREPORT \#181. Washington DC. www.microlinks.org/sites/microlinks/ files/resource/files/Rural_Agricultural_Finance_ Innovations.pdf

USAID (2012) ICT to enhance warehouse receipt systems and commodity exchanges in Africa. Briefing Paper. Washington DC. www.microlinks.org/sites/ microlinks/files/resource/files/FACETWRSCEXv2.pdf

USAID (2013) Development Credit Authority: final report of evaluations, 2008-2013.Washington DC. www.usaid.gov/sites/default/files/documents/2151/ DCA_Evaluations_Final_Report.pdf

USAID (2014) Rural livelihoods and food security: lessons from the Africa Regional Conference.

Washington DC. www.crackingthenutconference.com

USAID/Malawi (2013) Country Development Cooperation Strategy. Public Version, 2013-2018.

Washington DC. www.usaid.gov/sites/default/files/ documents/1860/Malawi\%20CDCS\%2020132018\%20-\%20Public\%20version.pdf

Vargas Hill, R et al. (2014) Using subsidies for inclusive insurance: lessons from agriculture and health. Microinsurance Paper No. 29. Microinsurance Innovation Facility, Geneva. www.microinsurancefacility. org/sites/default/files/MP29.pdf

VillageCapital (no date) www.vilcap.com/programs/ upcoming-programs

Wilson, K (2010) Jipange Sasa: a little heaven of local savings, hot technologies and formal finance. In: Wilson, $\mathrm{K}$ et al. (eds) Financial Promise for the Poor: How Groups Build Microsavings. Kumarian Press, Sterling, VA, 99-108.

WOCCU (no date) www.woccu.org.mx/esp/index_esp. php?id_menu $=1$

World Bank (2007) Providing financial services in rural areas: a fresh look at financial cooperatives. Agriculture and Rural Development Department, Washington DC. www.microfinancegateway.org/sites/default/files/mfgen-paper-providing-financial-services-in-rural-areas-afresh-look-at-financial-cooperatives-2007.pdf 
World Bank (2011) Weather index insurance for agriculture: guidance for development practitioners. Agriculture and Rural Development Discussion Paper No. 50. Washington DC. www. agriskmanagementforum.org/doc/weather-indexinsurance-agriculture-guidance-developmentpractitioners

World Bank and IFC (International Finance Corporation) (2009) Financial infrastructure: building access through transparent and stable financial systems. Washington DC. http://documents.worldbank.org/curated/ en/2009/01/11415665/financial-infrastructure-buildingaccess-through-transparent-stable-financial-systems

Wright, GAN and Cracknell, D (2007) The market led revolution of Equity Bank. MicroSave Briefing Note \# 63. Lucknow, India. www.microsave.net/files/pdf/ BN_63_The_Market_Led_Revolution_of_Equity_Bank. pdf

Wright, GAN et al. (2000) Financial services associations in Uganda: a mid-term review. MicroSave, Lucknow, India. www.microsave.net/files/pdf/Financial_ Services_Associations_In_Uganda.pdf

YouTube (no date) www.youtube.com/ watch? $v=S g 4 T N f i X H g Y$ and www.vilcap.com/ meet-you-at-the-top-village-capital-and-juhudi-kilimosinnovations-for-agriculture-program-wraps-up-in-nairobiinvests-50000-apiece-in-ojay-greene-and-futurepump 
In spite of investments and policy reforms, Sub-Saharan African countries lag in supplying financial services for agriculture and rural areas. New products, delivery channels, and partnerships, along with greater attention to savings, provide fresh optimism that this situation will be corrected. This paper examines several examples, with special attention to developments with savings groups and financial innovations with mobile phones and information and communication technologies (ICT). The telecom revolution and other innovations suggest that their use may leapfrog some difficult transportation and communication problems that drive up transaction costs and risks, and restrict financial inclusion for the poor.

IIED is a policy and action research organisation. We promote sustainable development to improve livelihoods and protect the environments on which these livelihoods are built. We specialise in linking local priorities to global challenges. IIED is based in London and works in Africa, Asia, Latin America, the Middle East and the Pacific, with some of the world's most vulnerable people. We work with them to strengthen their voice in the decision-making arenas that affect them - from village councils to international conventions.

\section{iied}

International Institute for Environment and Development 80-86 Gray's Inn Road, London WC1X 8NH, UK

Tel: +44(0)20 34637399

Fax: +44 (0)20 35149055

email: info@iied.org

www.iied.org

Funded by: 